\title{
Estratégia de desenvolvimento e combate à pobreza
}

ROBERTO CAVALCANTI DE ALBUQUERQUE

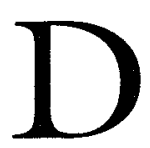

A COMPREENSÃo contemporânea do desenvolvimento como processo global, ou seja, envolvendo múltiplas e complexas inter-relaçốes entre o econômico, o social e o político, emergem seus três objetivos: a eficiência, a eqüidade e a liberdade (1).

O grau de alcance, por uma sociedade, do objetivo eficiência, de natureza mais econômica, pode ser aferido pelo Produto Interno Bruto (PIB) per capita, que é, na verdade, um indicador de produtividade (2). O objetivo equiidade é geralmente mensurado através de índices de desigualdade relativa da distribuição interpessoal da renda, o mais conhecido deles sendo o Coeficiente de Gini (3). Sobretudo de caráter político, o objetivo liberdade, de precária quantificação, tem sido avaliado a partir de indicadores relativos a participação política, segurança pessoal, liberdade de expressão, eficácia da lei e, em geral, ao exercício dos direitos e deveres da cidadania (4).

O cerne do drama experimentado historicamente pelo desenvolvimento reside na incessante e, muitas vezes, frustrante busca de conciliação desses três objetivos.

Talvez, ainda que com alguns riscos, possa se dizer que esse anseio está presente no imaginário político do Ocidente desde o Iluminismo, embora somente tenha começado a tomar concretamente forma com a gradual emergência, a partir de fins do século XVII, das naçốes-estados modernas do Noroeste da Europa. No que aqui interessa, a Revolução Industrial pode ser vista como o salto qualitativo na eficiência da produção, e a Revolução Francesa e seus desdobramentos - tanto os ideológicos, em particular o ainda chamado socialismo utópico, quanto os pragmáticos, mormente a progressiva universalização da educação formal, pública e leiga -, como engendrando as transformações que vão, com o passar do tempo, resultar em mais liberdade e em mais equiidade.

A modernidade dos países considerados desenvolvidos (seja da Europa, seja da América do Norte, seja do Leste Asiático e do Pacífico (5)), hoje uma modernidade tríplice (6), embora combinando eficiência, eqüidade e liberdade 
em graus bastante diferenciados, não foi obtida de modo historicamente concomitante, nem através de trajetórias de evolução nacional equilibradas. Em alguns casos - e muitas vezes por longos e descontínuos períodos de tempo -, a eqüidade foi preterida pela eficiência ou pela liberdade; em outros, a liberdade viu-se sacrificada para dar lugar a mais eqüidade ou eficiência; em outros ainda, a eficiência foi postergada em nome da equiidade ou da liberdade. É fato, porém, que esses países, havendo conquistado níveis relativamente altos de eficiência (representada por PIBs per capita superiores a US\$ 8.000 anuais (7)), encontram-se melhor equipados para equacionar seus problemas sociais e políticos.

No extremo oposto, os países subdesenvolvidos (8), em mais de um sentido ainda pré-modernos, não tendo resolvido suas questóes de eficiência produtiva, enfrentam grandes dificuldades para solucionar seus desafios sociais e políticoinstitucionais. Embora seus níveis de desigualdade relativa não sejam necessariamente elevados, são muito altas suas incidências de pobreza crítica. E são em geral muito baixos os graus de liberdade política e de estabilidade institucional (9).

Entre os dois extremos situam-se os países em desenvolvimento (10), que vivenciam os paradoxos de uma modernidade incompleta e inorgânica. Embora venham em geral atingindo patamares relativamente elevados de diferenciação $\mathrm{e}$ complexidade econômica (inclusive, em muitos casos, considerável grau de industrialização), esse processo é comumente desigual, setorial e espacialmente, determinando grandes, ainda que quase sempre decrescentes, diferenciais internos de eficiência produtiva. Essas desigualaçóes econômicas refletem-se em disparidades sociais (interpessoais, inter-regionais, urbano-rurais), èm vários casos agravadas por assimetrias na distribuição do capital humano, ou por outros fatores de ordem histórico-cultural. Por sua vez, esses desequilíbrios sócio-econômicos interagem com formas de institucionalização do poder de tendências oligárquicas, de que redundam performances modestas no que respeita aos indicadores políticos (11).

A diversidade das situaçóes nacionais dos países em desenvolvimento e os padróes diversos de sua evolução nas últimas décadas dificultam qualquer tentativa de generalização. Pode-se, contudo, com alguma segurança dizer que, nos últimos anos, a incidência de pobreza tendeu a reduzir-se bastante rapidamente com o crescimento econômico continuado, bem como que não se observam correlaçóes significativas, seja entre os níveis de renda, medidos pelos PIBsper capita, e os graus de desigualdade relativa, expressos pelos Coeficientes de Gini, seja entre esses últimos indicadores $e$ as incidências de pobreza.

A modernidade tríplice dos desenvolvidos, objetivo que se presume venha sendo perseguido pelos países subdesenvolvidos e em desenvolvimento, não será certamente alcançada através de sequiências equilibradas de progresso. É pouco 
prováxel, contudo, que ela seja mais rápida e eficazmente obtida mediante a eleição de um dos objetivos do desenvolvimento - seja ele a eficiência, a eqüidade ou a liberdade -, em detrimento dos outros dois. Estão de há muito anacrônicas as teses deterministas que submetem o social e o político ao econômico, substituídas pelo reconhecimento das múltiplas e complexas implicações entre essas três dimensôes do desenvolvimento, que são, na realidade, indissociáveis.

Dentro dessa ordem de idéias, as altas incidências de pobreza crítica encontradas nos países subdesenvolvidos ou em desenvolvimento, comumente consideradas apenas como problemas sociais, têm, na verdade, óbvias implicaçóes econômicas e políticas. De uma parte, a pobreza pode retardar ou comprometer o crescimento econômico, sej̣a por limitar a capacidade produtiva dos recursos humanos, seja por inibir a expansão do mercado interno. De outra, a incapacidade de contigentes significativos da população de prover, por seus próprios meios, suas necessidades básicas é a própria negação da liberdade e da eqüidade e pode ser capaz de gerar conflitos sociais politicamente desestabilizadores.

A pobreza é, portanto, para os países menos desenvolvidos, questão central a ser enfrentada na formulação e execução das diversas estratégias nacionais de desenvolvimento.

Considerado esse contexto, nosso objetivo neste estudo é o de conceber, a partir da análise e interpretação da pobreza no Brasil e de suas diferenciadas situações, rurais e urbanas, modelos de intervenção voltada a seu combate, inseridos na estratégia nacional de desenvolvimento. Modelos que possam vir a ser relevantes para a formulação de ações antipobreza no Brasil, além de terem, eventualmente, alguma validade como paradigmas para outros países, subdesenvolvidos ou em desenvolvimento.

O pressuposto teórico subjacente a esta abordagem é o de que as estratégias de intervenção planejada em situaçôes sociais, embora tenham objetivos preestabelecidos, devem definir-se a partir do conhecimento de seus objetos. Ou seja, de que é antes necessário conhecer e interpretar analiticamente a realidade para, em seguida, conceber os cursos de ação com maiores possibilidades concretas de modificá-la.

- Para que possam constituir referencial às açóes antipobreza, os modelos propostos, especificados de acordo com situaçôes sociais previamente analisadas e interpretadas, posicionam-se, com relação a programas ou projetos; em nível de maior generalidade (isto é, são entendidos como molduras, nas quais eles poderão vir a enquadrar-se).

Por outro lado, embora se reconheça que as situações com elevada incidência de pobreza, em si já bastante complexas, inserem-se em contextos societários 
mais amplos (com os quais elas interagem multiplamente), intenta-se evitar, nos modelos, tanto a excessiva abrangência quanto o equívoco oposto: a simplificação mutilante. No primeiro caso, a perda seria de acuidade; no segundo, de relevância - e, em ambos, comprometer-se-ia a eficácia de programas ou projetos que tomem os modelos como enquadramento.

Para atalhar esses dois descaminhos, procura-se identificar as variáveis estratégicas, com fundamento na análise interpretativa das situações sociais consideradas, bem como as inter-relações entre elas, realçadas nos modelos propostos com o objetivo de torná-los ferramentas úteis à programação das mudanças sociais que as ações antipobreza objetivam.

Os modelos especificam, a partir dessas variáveis, as açóes estratégicas resultantes, além de considerar as medidas complementares decorrentes do exame das características mais significativas das situações de pobreza consideradas.

\section{Pobreza no Brasil: análise e interpretação}

O número de pobres no Brasil em 1990 era de 39, 2 milhóes, correspondentes a $27 \%$ da população (145,4 milhôes) (12).

A dimensão continental do país, as diferenciações estruturais de sua economia, sua diversidade espacial, as disparidades regionais, sub-regionais e urbanorurais de níveis de desenvolvimento fazem com que, no complexo mosaico social brasileiro, ocorram situações de pobreza extremamente variadas. As incidências de pobreza, por exemplo, variam de $69 \%$ no Nordeste rural a $6 \%$ na regiáo metropolitana de São Paulo; inversamente, a distância social entre pobres e nãopobres (13), de apenas 4,8 no meio rural do Nordeste, alcança 17,6 na Grande São Paulo. A despeito da pequena variação verificada na renda média dos pobres, seja entre as marcrorregióes e regiốes metropolitanas, seja entre os meios rural e urbano, são grandes os diferenciais de níveis de vida entre os pobres metropolitanos, urbanos não-metropolitanos e rurais (14).

\section{Crescimento e redução da pobreza}

Quando se examina a evolução, nos últimos anos, dos níveis de pobreza crítica, no Brasil como um todo, em confronto com o desempenho global da economia, verifica-se elevada correlação entre o crescimento do PIB per capita e a redução da pobreza.

Com efeito, entre 1970 e 1980, enquanto o produto interno bruto (PIB) per capita nacional exibiu crescimento de $81 \%(6,1 \%$ ao ano), a pobreza crítica se 
reduziu de 44,7 milhões de pessoas (47\% da população) para 29,5 milhões (25\%). Nos anos 80, contudo, o número de pobres se elevou para 39,2 milhóes (1990), correspondentes a $27 \%$ da população, enquanto o PIB per capita declinou $4 \%$ $(0,4 \%$ ao ano $)$.

Embora os efeitos do crescimento sobre a redução da pobreza sejam amplamente reconhecidos, o acontecido no Brasil na década de 1970 ficou, pelo menos até recentemente, obscurecido pelo debate gerado em torno das desigualdades relativas de renda, as quais se mantiveram, no período, em patamares extremamente elevados.

A esse propósito, seria de observar-se que o grande aumento nas desigualdades relativas de renda do país ocorreu na década de 1960, quando o Coeficiente de Gini se elevou de 0,50 para 0,57 (15). Os estudos mais recentes realizados sobre os anos 70, ou concluem por um pequeno aumento desse coeficiente, ou por uma leve reduçáo dele (16), além de registrarem uma importante expansáo tanto dos rendimentos médios, em todos os decis, quanto do emprego, bem como significativa queda da proporçáa das pessoas sem rendimento na população economicamente ativa.

Na verdade, balanço da situação social do Brasil na década de 1970, realizado para o Fórum Nacional, concluiu que o dinamismo económico verificado no período foi acompanhado de processo de convergência social, envolvendo, além da redução da pobreza já referida, a elevação da participação dos $40 \%$ mais pobres na renda, a diminuição das disparidades inter-regionais e urbano-rurais de níveis de bem-estar e a emergência de uma sociedade de consumo em massa (17).

\section{O precário desempenho dos programas antipobreza}

Entretanto, têm sido muito modestos os resultados das intervençōes públicas direcionadas ao combate à pobreza no país.

Com efeito, tomem-se como exemplo desse pobre desempenho os programas de desenvolvimento rural integrado executados no Nordeste, desde meados dos anos 70, o maior e mais abrangente esforço de redução da pobreza jamais realizado no país.

Desde 1974, os governos da União e dos estados daquela região vêm empreendendo, com o apoio do Banco Mundial, grande programa de desenvolvimento rural integrado, voltado para a população de baixa renda. Foram destinados aos 23 projetos aprovados recursos da ordem de US\$ 4 bilhóes (dólares de 1988), dos quais US\$ 1,7 bilhão foi obtido, mediante empréstimos, do Banco Mundial. Esses projetos elegeram, como público-alvo, quase um milhão de famí- 
lias rurais pobres (cerca de cinco milhões de pessoas) em área que acabou correspondendo a virtualmente todo o Nordeste rural (do Maranhão até a porção de Minas Gerais incluída no Polígono das Secas).

Uma primeira geração de doze projetos (1975-84), integrantes do Polonordeste (18), envolvendo US\$ 1,9 bilhão, concentrou-se em áreas selecionadas, totalizando $500 \mathrm{mil} \mathrm{km}^{2}$ (cerca de $1 / 3$ do Nordeste), e pretendia beneficiar $\mathbf{2 8 0}$ mil famílias pobres. Estruturalmente complexos, dadas suas características de intervenção abrangente do tipo big push (19), esses projetos, embora concentrados espacialmente, contemplaram desde a infra-estrutura de transporte e energia e a reorganização fundiária até o apoio à produção e à comercialização agrícolas (irrigação, extensão e crédito rurais, pesquisa agrícola, comercialização) e a infra-estrutura e os serviços sociais (saúde, educação e treinamento de mãode-obra, abastecimento d'água). Essa complexidade buscava tirar partido da complementaridade entre os diversos componentes, concentrados geograficamente em áreas de elevado potencial agrícola (20), julgados capazes de gerar efeitos sinérgicos propiciadores da elevação da produtividade e da renda dos produtores rurais beneficiados.

Uma avaliação independente da execução desses projetos, realizada em 198889 (21), evidenciou resultados muito desiguais, se considerados os desempenhos de seus vários componentes. É verdade que foram despendidos, nos dez projetos sobre os quais se obtiveram informaçóes mais completas, cerca de $2 / 3$ dos recursos programados, beneficiando, de um ou de outro modo, um número de famílias maior do que o inicialmente previsto. Contudo, os componentes de infraestrutura básica (estradas, eletrificação rural, abastecimento d'água e, inclusive, reforma agrária), bem como os sociais (saúde e educação), foram considerados tanto muito melhor implementados quanto de maior impacto, quando comparados com os voltados mais diretamente para a o aumento da produção, da produtividade e da renda agrícola retida pelos pequenos produtores rurais (crédito, extensão rural e assistência técnica, comercialização) (22). Ou seja, foram justamente aqueles componentes que demandavam participação ativa dos beneficiários, como agentes econômicos capazes de assimilar e praticar novas técnicas de produção, além de inserirem-se mais amplamente no mercado, que revelaram mais pobre desempenho.

Uma segunda geração de onze projetos (1985-89), integrantes do Papp (23), embora tenha consideravelmente reduzido o número de componentes - abandonando a infra-estrutura, a educação e a saúde, concentrando-se naqueles segmentos mais diretamente vinculados à produção agropecuária (como o acesso à terra, o crédito e a extensão rural) e dando grande ênfase a um novo componente, o desenvolvimento comunitário -, ampliou grandemente tanto a área beneficiada ( 1,4 milhão de $\mathrm{km}^{2}$, quase todo o Nordeste) quanto o total dos potenciais bene- 
ficiados: quase $\mathbf{7 0 0}$ mil famílias. As duas medidas - a concentração do programa nos componentes que, malgrado essenciais, no passado tinham se revelado de difícil execução, e a indiscriminada extensão da área de atuação -, a par de impecilhos conjunturais (de financiamento, com recursos internos, e de natureza político-institucional), comprometeram seriamente a execução do Papp.

Esses obstáculos, além de dúvidas sobre a própria eficácia do programa, determinaram nova revisão de seu conteúdo e estratégia (realizada em 1991-93), a qual caminhou para reforçar ainda mais a autodeterminação dos projetos, confiando tanto seu desenho quanto sua gestão aos próprios beneficiários.

Não existe análise, abrangente e atualizada, do impacto econômico-social dos projetos de desenvolvimento rural do Nordeste. Recentemente reformulados e com sua execução redinamizada desde fins de 1993, eles voltam a despertar novas esperanças, com suas ênfases na descentralização e autogestão, na eleição de componentes pelas comunidades, nos projetos de pequeno porte, na inclusão de ações especificamente voltadas para as pequenas cidades, compreendidas, adequadamente, como núcleos urbano-rurais. Porém ainda transpira, entre Washington, Brasília e aquela região, sensação de desconforto e de descrédito com relação a ambos os modelos anteriores de intervenção, às formas de sua execução e à própriaperformance das populações participantes, agora promovidas a árbitros de suas necessidades e a atores de sua inserção produtiva e ascensão social.

É fato, entretanto, que, a despeito do meritório esforço representado pelo Polonordeste, pelo Papp e seus desdobramentos, a pobreza rural daquela regiāo, que se reduzira de 13,2 milhôes ( $88 \%$ da população) em 1970 para 11 milhóes ( $66 \%$ da população) em 1980 - em grande medida devido às migraçóes, uma vez que os efeitos do crescimento sobre a pobreza são sabidamente muito mais significativos no meio urbano do que em economias rurais ainda em grande medida de auto-subsistência -, elevou-se para 12,6 milhões (69\% da população) em 1990. E não há, infelizmente, como aferir o quanto pior teria sido essa involução na ausência daqueles programas.

\section{Situações de pobréza: perfis}

Pesquisas anteriores (24), que examinaram, com fundamento em um conjunto de indicadores econômicos e sociais, as diferentes características e a diferenciada evolução, nos últimos anos, da pobreza no Brasil, embasam a escolha, para os propósitos deste estudo, de três situações de pobreza crítica no país: o Nordeste rural, o Sudeste metropolitano e o Nordeste urbano.

Os critérios de seleção dessas situações de pobreza levaram em conta a grande dimensão e a alta incidência da pobreza, relativamente às brasileiras (casos 
do Nordeste rural e urbano); a rapidez de sua expansão ao longo dos últimos anos (caso do Sudeste metropolitano); a variada influência, sobre o número de pobres, do crescimento econômico (que atua como grande redutor de pobreza no Sudeste metropolitano, tem menor impacto relativo no Nordeste urbano e é pouco significativo no Nordeste rural); o papel das migraçóes internas (que atenuam a dimensão da pobreza rural no Nordeste e a ampliam nas metrópoles do Sudeste e nas cidades nordestinas); e os efeitos, sobre os níveis de vida, da extensão, às áreas de concentração de pobreza, das diversas políticas sociais públicas (com presença mais significativa no Sudeste metropolitano, relevante no Nordeste urbano e menos importante no meio rural dessa última região) (25). Para os efeitos das classificaçôes internacionais referidas na introdução deste estudo, 0 Nordeste rural pode ser considerado como de baixa renda ou subdesenvolvido, $\mathrm{e}$ o Sudeste metropolitano e o Nordeste urbano, como em desenvolvimento, o primeiro apresentando renda média alta e o segundo, renda média baixa.

\section{O Nordeste rural: a pobreza como destino}

A pobreza no meio rural do Nordeste tem caráter endêmico e é, econômica, social e psicossocialmente, de natureza estrutural. Torna-se visível em seus três mundos: no mundo da natureza, no mundo social e no mundo intra-subjetivo (26). Explicita-se, porém, pragmaticamente, nas relações, protagonizadas pelo homem, seja com a realidade objetiva, seja com seus semelhantes, seja consigo mesmo.

Os 12,6 milhóes de depauperados do Nordeste agrário (27) representam $63 \%$ da pobreza rural do país (28) e $32 \%$ dos pobres brasileiros. Sua renda familiar per capita, de US\$ 201 anuais, equivale a $89 \%$ da dos pobres do país e a $48 \%$ da renda correspondente à linha de pobreza adotada neste estudo (US\$ 417). Os pobres rurais nordestinos, sendo $9 \%$ dos brasileiros, auferem menos de $1 \%$ da renda familiar nacional.

Os pobres do Nordeste rural seriam certamente muito mais numerosos na ausência das grandes migrações rural-urbanas verificadas ao longo das últimas décadas, que operaram, o mais das vezes, meras transferências inter-regionais e intra-regionais de pobreza. Com efeito, na década de 1960, o volume líquido de emigrantes do Nordeste rural foi de 4,1 milhões, dos quais $42 \%$ ficaram retidos no meio urbano regional, com os restantes $58 \%$ seguindo para outras regióes, em especial para as grandes metrópoles do Sudeste. Nos anos 70, aquele volume foi de 4,6 milhões, com as cidades do Nordeste apresentando maior poder de absorção: $63 \%$ (2,9 milhões) (29). Isto significa que o Nordeste agrário tem revelado baixíssima capacidade de retenção relativa do crescimento vegetativo de sua população: de $28 \%$ dele na década de 1960 e de $16 \%$ na década de 1970 (30). Nos anos 80, essa capacidade de retenção tornou-se negativa porquanto o Nordeste 
apresentou redução de $3 \%$ em sua população rural (31), o que provavelmente se deveu ao efeito acumulado de acentuada queda na fecundidade, da mesma intensidade relativa das emigraçóes e de moderada redução da mortalidade.

Algumas outras características econômico-sociais da população pobre que continuava vivendo no Nordeste rural, em 1990, confirmam a persistência ali de situação de grandes carências. O número médio de dependentes por família era de 4,3 pessoas (comparados com 2,5 pessoas para os não-pobres). Só $65 \%$ das crianças (0-14 anos) freqüientavam a escola, $66 \%$ dos chefes de família não tinham qualquer instrução e menos de $4 \%$ deles tinham mais de quatro anos de escolaridade. Viviam da agricultura de auto-subsistência $83 \%$ dos chefes de família pobres, cuja renda familiar dependia em $76 \%$ daquela atividade. Apenas 3\% dos domicílios dispunham de alguma forma regular de abastecimento d'água e somente $7 \%$ tinham geladeira. Entre as famílias pobres consideradas socialmente mais vulneráveis, sobressaíam as chefiadas por mulheres ( $15 \%)$ e por pessoas de cor preta $(6 \%)$, com menos de 18 anos $(0,6 \%)$ ou com mais de 60 anos (18\%) (32).

Nesse contexto - e considerada a elevada incidência de pobreza, já referida -, não será preciso lembrar que o Nordeste rural em seu conjunto $e$, relativamente ao Brasil ou por qualquer outro critério que se venha a adotar, subdesenvolvido.

Com efeito, se sua população é $13 \%$ da brasileira, sua renda é somente $3 \%$. A renda familiar per capita anual dos não-pobres é de apenas US\$ 961 (sendo 4,8 vezes superior à dos pobres), e a do conjunto da população (US\$435) mal supera a linha de pobreza.

Se, deixando de lado o critério-renda, se consideram, ainda para o Nordeste agrário como um todo, alguns indicadores capazes de mensurar, mais concretamente, o grau de atendimento de necessidades humanas básicas, sua situação social revela-se ainda mais carente. Com efeito:

- no que respeita à educação, o percentual de crianças (7-14 anos), pobres e não-pobres, que freqüentam escola é de 67\% (Brasil, 84\%; Brasil rural, 72\%);

- nas relações de trabalho, a percentagem de empregados com carteira de trabalho assinada é de $31 \%$ (Brasil, 67\%; Brasil rural, $41 \%$ ) e o percentual de trabalhadores por conta própria, contribuintes da previdência social, é de $3 \%$ (Brasil, 22\%; Brasil rural, 7\%);

- no que respeita à condição dos domicílios, somente $7 \%$ deles dispóem de abastecimento d'água (Brasil, $63 \%$; Brasil rural, $12 \%$ ) e $15 \%$ possuem geladeira (Brasil, 69\%; Brasil rural, 36\%). 
$\mathrm{Na}$ verdade, utilizando-se índice agregado (o ICB), que mede o grau de atendimento das necessidades fundamentais das famílias brasileiras, $\mathrm{o}$ Nordeste rural obtém ICB de 165 (Brasil, 590; Brasil rural, 262) (33).

Note-se que os dados acima apresentados retratam situação social - o Nordeste rural - de grande expressão demográfica, ocupando espaço ecotropical diversificado, que não deve ser confundido com o Sertão árido territorialmente dominante. Integra-o, ao norte, a Pré-Amazônia maranhense; contorna-lhe o litoral atlântico a Mata úmida, que se prolonga na transição, do subúmido ao semiárido, característica do Agreste; e os Cerrados avançam fundo por seu flanco sudoeste. A essa variedade de paisagens correspondem antigas e pluriformes açóes antrópicas, perturbadas, nos últimos anos, por intromissões da moderna agricultura de mercado, adentrando-se, com a irrigação técnico-intensiva, pelo Sertão: elas são verdadeiros enclaves plantados nos domínios da agropecuária tradicional, em grande medida de auto-subsistência, que continua a padecer o alto e secular risco das secas.

Se esses influxos paradoxais de modernidade estão a atestar a viabilidade da agricultura e do desenvolvimento em pleno Polígono das Secas, eles também acentuam o contraste entre a riqueza possível a alguns poucos e a pobreza a que a maioria parece condenada. E se eles têm impacto sobre os níveis globais de produção e produtividade agrícolas, não detêm, contudo, a força necessária para alterar as tristes condições de vida de milhôes de deserdados.

Isto não significa, porém, que não existam inter-relacionamentos entre pobres e não-pobres no meio rural do Nordeste. Eles são intensos e fortemente estruturados na sociedade tradicional que ali se formou ao longo de três séculos, e conformam uma teia de laços que perpassam as relaçōes de família, de trabalho e de propriedade, bem como as formas instituídas de exercício do poder. A família no meio rural não é apenas a unidade nuclear moderna, centrada no casal $\mathrm{e}$ integrada pelos filhos: é um corpo social expandido, pluridomiciliar, que incorpora toda a parentela além de muitos agregados, superando as clivagens ricopobre e cidade-campo e urdindo vínculos de lealdade, sentimentos de responsabilidade e elos de dependência. No trabalho, há as várias formas de parceria, mais ou menos espoliativa, dos pobres pelos não-pobres, envolvendo o complexo agricultura de subsistência-agricultura comercial-pecuária. Nas relaçôes com a propriedade, ainda subsistem os moradores pobres sem terra das palhoças, ranchos ou mocambos espalhados pelas fazendas alheias, que nelas podem botar seus rogados em meação e ainda ajudam o dono da terra na criação de gado. E nas relações de poder, permanece importante a proteção que o pobre recebe de seu chefe coronel, tenente, capitão ou major -, geralmente proprietário rural de maiores posses, vivendo nas pequenas e médias cidades do interior, e que substitui ou representa, perante ele, as autoridades públicas (o governo). 
O que explica a persistência, por tanto tempo e em tão grande número, da pobreza rural do Nordeste? Por que ele continua gerando e exportando, indefinidamente, grandes contingentes de pobres? Qual a razão da pouca eficácia transformadora das açóes públicas antipobreza que têm sido ali empreendidas, em particular nos últimos vinte anos, a exemplo dos projetos de desenvolvimento rural integrado já analisados neste estudo?

A resposta a essas indagaçóes deve ser buscada muito mais em exame dé natureza psicossocial e antropológico das concepçōes do mundo e da existência que povoam as representaçóes mentais do homem rural do Nordeste, do que na tentativa de identificar as restriçóes, sobejamente conhecidas, que impóem a natureza e a ordem econômico-social em que ele se situa (34).

Com efeito, a visão que o homem rural do Nordeste tem da realidade objetiva, de seus semelhantes e de si próprio não é a do homem ocidental moderno, confiante em seus próprios poderes: no poder da razão, decifrador da realidade; no poder da ciência e da técnica, gerador de progresso e bem-estar; no poder, quase demiúrgico de criar a história, vencendo as incertezas inerentes ao futuro. Habitam as mentes do homem rural nordestino formas de percepção e de compreensão míticas, tradicionais e modernas, em confuso amálgama, intra-subjetivamente conflitivo, gerando, em muitos casos, imobilismo nas relações interpessoais e passividade ante os desafios da natureza.

Essa interpenetração de formas de conhecimento retém, da consciência mítica, a percepção, atemporal e pré-histórica, do mundo e da vida como repetiçáo continuada de uma totalidade indissociada do próprio homem (35); a valorização dos ritos como força de organização social; a crença nos poderes objetivos da magia (36); e uma certa indistinção entre natureza e cultura (37).

De outra parte, incorpora, das tradições do velho Ocidente europeu, conservadas em Portugal e transmitidas pela colonização, visão pré-moderna do mundo, associada ao catolicismo medieval, dogmático, ritualístico, profético, messiânico, que favorece, neste mundo, a aceitação contrita e passiva da miséria humana, acenando, no outro, com as promessas redentoras do paraíso (38).

A assimilação da consciência moderna ocorre, nesse contexto, de forma seletiva, incompleta, truncada. As reverberaçóes da civilização, que penetram, com intensidade crescente nas últimas décadas, aqueles espaços sociais, interessam ao homem rural pelos serviços $e$ amenidades que encerram - e pelas promessas de uma vida melhor que prenunciam. Elas não são, contudo, facilmente integradas por eles, nem se refletem em suas atitudes e comportamentos. De um lado porque essas mensagens de modernidade não lhe são transmitidas de modo estruturado e compreensivo. De outro lado porque a percepção delas pelo ho- 
mem rural tem os efeitos sobre sua conduta neutralizados pelas forças interditórias do mito e da tradição, cujo rationale implícito desconfia, defensivamente, de quaisquer novidades que possam vir a fragilizar suas bases de sustentação, comumente julgando-as com desfavor ou as vendo com indiferença.

Esses bloqueios de natureza cultural inibem a racionalidade instrumental como postura pragmático-formal básica perante a natureza e a sociedade - e, em decorrência, os modos de organização eficiente do trabalho e da produção; desestimula as inovaçóes ao reafirmar sua peculiar e rotineira liturgia da repetição; desconsidera a prática da poupança, sem significado num mundo que ainda não se introduziu inteiramente no tempo e na história e que, portanto, não é capaz de legitimá-la culturalmente.

É evidente que a mentalidade do homem rural do Nordeste está mudando à medida que a modernização avança, pelo interior, nas rodas dos caminhões $\mathrm{e}$ nas ondas do rádio e da televisão. Chegará o momento em que essas resistências cederāo, vencidas pela modernidade, que transporta com ela suas próprias formas de comportamento econômico. Esse processo de transformação, contudo, além de lento, dá-se mais por fora do que por dentro, só excepcionalmente atingindo o umbral a partir do qual começam a alterar-se, pela racionalização institucionalizada, as resistentes rotinas do trabalho e da vida cotidianos.

\section{O Sudeste metropolitano: o pobre na riqueza}

As três regiôes metropolitanas do Sudeste (São Paulo, Rio de Janeiro e Belo Horizonte), com $22 \%$ da população total do país e $29 \%$ da urbana, respondem, respectivamente, por $34 \%$ e $38 \%$ das rendas nacionais total e urbana (39).

As dimensões relativa e absoluta da pobreza metropolitana vêm sendo, no Brasil dos últimos anos, extremamente sensíveis às variaçốes da conjuntura econômica.

Em 1970, os pobres do Sudeste metropolitano eram dois milhōes, correspondentes a cerca de $15 \%$ de sua população total. Em meados da década (40), esse número caiu para 816 mil (4,5\% da população), com redução absoluta de $60 \%$ em período que engloba a fase da chamado milagre económico, no qual a renda metropolitana per capita cresceu $45 \%$ (7,7\% anuais).

Em contrapartida, no período seguinte, globalmente de estagnação, situado entre meados dos anos 70 e final dos 80 , a pobreza metropolitana expandiu-se dos mencionados 816 mil para 2,9 milhóes, com a renda metropolitanaper capita decrescendo $27 \%$ ( $2 \%$ ao ano) (41). 
De outra parte, é singular, no Brasil, o contraste entre os pobres e os nãopobres que se observa em suas três maiores regiōes metropolitanas.

Em 1990, os 3,1 milhões de pobres dessas regióes (8\% dos pobres do país), correspondiam a quase $10 \%$ da população, porém detinham apenas $0,8 \%$ da renda metropolitana: em São Paulo, a incidência de pobreza era $6 \%$ e a participação dos pobres na renda, $0,4 \%$; no Rio de Janeiro, esses valores eram $13 \%$ e $1,4 \%$; e em Belo Horizonte, $16 \%$ e $1,7 \%$, respectivamente.

Medida pelo critério da renda, a distância social entre pobres e não-pobres nas três regiōes era de 13,2 (42), com a renda média familiar dos pobres sendo US\$226 e a dos não-pobres, US\$2.991. Essa distância cresce, entre as três regióes, à medida que se eleva a renda média dos não-pobres, sendo de 10,8 no Rio de Janeiro (com renda média dos não-pobres de US\$2.688), 11,1 em Belo Horizonte (US\$2.694) e, conforme já referido, 17,6 em São Paulo (US\$ 3.232). Vale ainda observar que, para o conjunto das três metrópoles nacionais, se a renda per capita dos pobres equivale à brasileira (elas são US\$ 226 e US\$225, respectivamente), a dos não-pobres é 28\% maior (US\$ 2.991 e US\$ 2.342), sendo a dos pobres e náo-pobres, juntos, $54 \%$ mais elevada (US\$2.723 e US\$ 1.772) (43).

Esses dados sugerem, por um lado, um nivelamento por baixo da população pobre brasileira, provavelmente operado pelas migraçóes, dedução que se reforça quando se observa que a renda familiarper capita dos pobres rurais do país é de US\$214, a dos urbanos, US\$237 e a dos metropolitanos, US\$230. E, por outro, revelam graus de desigualdade crescentes entre pobres e não-pobres, à medida que se elevam os níveis de renda - ilação que se impóe se salientado que a distância social entre esses dois grupos é de 5,6 no Brasil rural, 10,8 no urbano e 12,5 no metropolitano.

Essas conclusões, contudo, precisam ser melhor qualificadas.

Com efeito, quando se examina, a partir de indicadores sociais selecionados, o grau de atendimento das necessidades básicas dos pobres do Sudeste metropolitano, em confronto com os dos pobres rurais, urbanos e metropolitanos do Brasil em seu conjunto, chega-se à constatação de que ali são mais elevados os níveis de bem-estar por eles alcançados:

- no Sudeste metropolitano, o percentual de crianças pobres (7-14 anos) freqüentando a escola é de $83 \%(67 \%, 81 \%$ e $83 \%$, respectivámente no Brasil rural, urbano e metropolitano);

- o percentual de empregados com carteira assinada é de $65 \%$ (Brasil rural, 25\%; urbano, $44 \%$; metropolitano, $59 \%$ ); 
- o percentual de domicílios com abastecimento d'água atinge $74 \%$ (4\%, $54 \%$ e 64\% para os Brasis rural, urbano e metropolitano);

- a porcentagem dos domicílios com geladeira chega a $77 \%$ (Brasil rural, $16 \%$, urbano, $48 \%$ e metropolitano, $64 \%$ ); e

- o ICB para o Sudeste metropolitano pobre, de 463 , indica que o grau de atendimento das carências básicas é ali muito mais elevado do que no.Brasil rural (136), urbano (366) ou mesmo metropolitano (438) (44).

Como a renda média familiar dos pobres das metrópoles do Sudeste equivale à brasileira, é provável que esses diferenciais de condiçóes de vida se expliquem pelas maiores facilidades de acesso dos pobres metropolitanos à educação, ao mercado organizado de trabalho, aos serviços públicos domiciliares e até aos bens duráveis de consumo. Acesso esse devido muito mais às melhores condiçóes da oferta, em grande medida pública, desses serviços e bens do que a demanda associada ao nível de renda (45).

O número médio de pessoas por família pobre no Sudeste metropolitano (4,1 pessoas: 4,5 em Belo Horizonte, 4 no Rio de Janeiro e 3,9 em São Paulo) é bem menor do que no Nordeste rural $(5,3)$ e urbano $(4,6)$. É porém superior ao das famílias não-pobres (3,4, sendo 3,6 em Belo Horizonte, 3,5 em São Paulo e 3,2 no Rio de Janeiro). A dependência familiar da renda dos chefes de família pobres é de $76 \%$, com duas pessoas em idade ativa ( 15 anos e mais) por família gerando os restantes $24 \%$ da renda. Essa dependência é menor entre os nãopobres $(72 \%$, com $28 \%$ da renda familiar sendo gerados por 1,9 pessoa em idade ativa), o que sugere haver bastante espaço entre os pobres para intensificação do uso do trabalho como forma de complementação de renda.

As famílias pobres chefiadas por mulheres chegam a $36 \%$ no Sudeste metropolitano (38\% no Rio de Janeiro e 35\% em São Paulo e Belo Horizonte), comparados com $21 \%$ para as não-pobres (24\% em Belo Horizonte, $23 \%$ no Rio de Janeiro e $19 \%$ em São Paulo). Esse percentual, sendo mais alto do que o encontrado para o Brasil urbano (33\%), indica que a desestruturação da família, já maior no meio urbano nacional do que no rural, agrava-se mais nas três metrópoles do Sudeste. Outras famílias potencialmente mais vulneráveis são as chefiadas por menores de 18 anos (1\%) e maiores de 60 anos (12\%), além daquelas cujos chefes de família são de cor preta (10\%) (46).

Variam consideravelmente, entre as três regiōes, tanto a participação de pessoas de cor entre os chefes de família quanto as correspondências entre cor e pobreza. No Rio Janeiro, $16 \%$ dos pobres são de cor preta ( $9 \%$ dos nãopobres), $41 \%$ de cor parda (30\% dos não-pobres); em Belo Horizonte, $14 \%$ 
dos pobres são pretos ( $8 \%$ dos não-pobres), $56 \%$ pardos ( $39 \%$ dos não-pobres); em São Paulo, $5 \%$ dos pobres são pretos (4\% dos não-pobres), $34 \%$ pardos (23\% dos não-pobres).

No conjunto das três regióes metropolitanas, são as atividades de serviços, comércio e construção civil (nesta ordem de importância) que concentram o maior número de chefes de família pobres, destacando-se, no Rio de Janeiro e em São Paulo, o setor informal de serviços e, em Belo Horizonte, a construção civil.

Embora as taxas de analfabetismo dos chefes de família pobres sejam menores do que as nacionais nas três regiốes (São Paulo, 21\%; Belo Horizonte, $19 \%$, Rio, $16 \%$, comparados com $35 \%$ para o Brasil urbano), o analfabetismo funcional (pessoas sem instrução ou com até quatro anos de escolaridade) ainda é muito elevado: $76 \%$ em Belo Horizonte, $66 \%$ em São Paulo e 55\% no Rio de Janeiro, comparados com $76 \%$ para o Brasil urbano.

Diferentemente dos pobres rurais do Nordeste, que apresentam características econômicas e psicossociais relativamente mais uniformes, as situações de pobreza do Sudeste metropolitano são extremamente diversificadas, constituindo-se sua compreensão um sério desafio para o desenho de modelos de intervenção eficazes a seu combate.

Não é suficiente, para entendê-las, tomá-las como uma totalidade capaz de auto-explicar-se a partir das formas dominantes de sua organização social e dos padróes de conduta e modos de agir dos indivíduos que as integram (47). Tampouco é bastante considerá-las como decorrência do processo histórico global em que essas situações sociais (e as metrópoles que as abarcam) se situam (48). Embora essas abordagens possam ter sua utilidade, elas em geral não se detêm no exame das relaçóes que se estabelecem, dentro das cidades, entre os pobres e os não-pobres, nem na consideração do significado de sucessivas ondas migratórias que permanentemente transferem grandes contingentes de pobres do campo para as cidades, de certo modo diluindo nelas a tradicional antítese entre o rural e o urbano.

As múltiplas e multiformes relações entre os pobres e os não-pobres dentro das três metrópoles nacionais levam, com efeito, a questionar o que nelas significa marginalidade urbana - ecológica, econômica ou culturalmente -, bem como a indagar em que medida é possível associar, linearmente, marginalidade a pobreza.

Ecoespacialmente, a marginalidade urbana seria constituída pelos chamados assentamentos humanos subnormais (favelas), ou seja, por aqueles em que as condiçóes de ocupação do solo, de habitação e, em geral, de meio ambiente são vistas como desordenadas, precárias e degradadas com relação aos padrões normais prevalecentes nas metrópoles. Não há, porém, como confundir, nas regióes 
em exame, todas as favelas com o locus necessário da pobreza (sobretudo da pobreza crítica, tal como conceituada neste estudo): embora elas sejam, em geral, espaços de maior concentração de pobreza, muitos dos que hoje as habitam não são pobres (alguns nunca o foram); e nem todos os pobres têm acesso fácil a todas elas (49).

Do ponto de vista econômico, a marginalidade seria caracterizada pela exclusão dos pobres da economia urbana moderna. Não há, contudo, razão suficiente para considerar economicamente excluídos da modernidade os chefes de família que, malgrado pobres, trabalham na indústria de transformação ( $22 \%$ do total deles em São Paulo, 16\% no Rio de Janeiro e 14\% em Belo Horizonte) ou em outras atividades, secundárias e terciárias, que indiscutivelmente se inserem nos modos de organização racional da produção próprios do capitalismo moderno. E, de outra parte, seria difícil negar a funcionalidade - e complementaridade - do comércio ambulante e outras atividades informais de serviços, exercidas (comumente por pessoas pobres) de modo bastante integrado e articulado às formas de produção dominantes e às demandas associadas aos modos de vida dos não-pobres.

Culturalmente, não há base empírica para afirmar que os pobres metropolitanos permanecem, em sua totalidade, impermeáveis ao mundo moderno em suas variadas manifestações, constituindo uma subcultura radicalmente à parte da cultura nacional vivida pela cidade envolvente. Ao contrário, os diversos graus de aculturação ou de conversão ao espírito moderno observados entre eles é que têm levado, por exemplo, alguns estudiosos das favelas do Rio de Janeiro a considerar, alternativamente, os pobres seja como marginais, seja como integrados (50).

O que parece sensato admitir é que os pobres metropolitanos do Sudeste constituem uma complexa heterogeneidade e que, embora continuando pobres, protagonizam uma inserção dinamicamente diferenciada na grande cidade. Os graus variados dessa integração sujeitam-se a múltiplos fatores. De uma parte, ao tempo de vivência metropolitana ou urbana deles, os nascidos nas grandes cidades tendendo a apresentar vantagens na sua integração social sobre os migrantes das pequenas cidades ou do meio rural ( $\mathrm{e}$, por sua vez, os migrantes mais antigos sendo favorecidos nesse processo, relativamente aos mais recentes). De outra parte, dependem do nível de educação formal alcançado, que tende a ser mais elevado na população mais jovem, e das experiências de trabalho e de viver urbanos experimentadas, mecanismos estes de sociabilização tardia porém certamente muito eficazes.

Seriam justamente os pobres mais integrados que estariam melhor habilitados a se beneficiar mais do crescimento da economia urbana organizada e a assumir as diversas funçóes que a sociedade moderna propicia aos indivíduos que dela 
realmente participam: os papéis de produtor e de consumidor, de contribuinte e cliente do Estado, bem como os direitos e deveres inerentes à cidadania (51).

É de notar-se, contudo, que somente o exercício continuado dessas funçôes sociais engendra o processo de individualização, de autodisciplina e, em geral, de racionalização da vida, características do homem ocidental moderno, processo que, com o tempo, se torna irreversível.

Essa irreversibilidade, entretanto, ainda não teria ocorrido para a maioria dos pobres das três metrópoles do Sudeste, os quais, ao contrário, submetem-se muitas vezes, nas próprias favelas, ao jugo de poderes paralelos quase absolutos $\mathrm{e}$ a vivências humanas que reforçam, atavicamente, as molduras que circunscrevem as sociedades primitiva e tradicional, nas quais eles ainda em parte remanescem.

Com efeito, a marginalidade - agora denotando conduta delituosa - que, sobretudo nos morros e baixadas cariocas e fluminenses, se manifesta no crime organizado, neles constrói complexas estruturas de domínio, que ignoram, desafiam ou cooptam os poderes do Estado. Essas formas de dominação estabelecem redes de relações com as metrópoles envolventes que, malgrado desviantes, são a razão de ser de sua sobrevivência. E de certo modo reproduzem no meio urbano o personagem ambíguo - benfeitor e espoliador, justiceiro e criminoso, protetor e algoz - do coronel, seu protótipo rural (52).

Esses poderes espúrios utilizam-se dos pobres como suas massas de manobra. Sem alternativas de trabalho, ignorados por um Estado que quase sempre se diz ausente, muitos deles acabam, de um ou de outro modo, cedendo, por adesão, leniência ou temor, a um violento e ancilar império, facilmente acoplado aos arquétipos mentais que sua memória ainda carrega de passado social não muito distante.

É nesse caldo de cultura que se instala, enraíza e prospera o crime organizado.

\section{O Nordeste urbano: a pobreza rurbana}

O Nordeste urbano, tomado em seu conjunto, ainda não é, relativamente ao Brasil, espaço social desenvolvido. Numa escala internacional, poderia ser considerado como de renda média baixa.

Sua população, correspondendo a $17 \%$ da brasileira ( $23 \%$ da urbana), detém menos de $12 \%$ da renda nacional (menos $13 \%$ da urbana). Sua renda familiar per capita, de US\$ 1.236 , se é 2,8 vezes superior à renda rural regional, corresponde, no entanto, a $70 \%$ da brasileira como um todo e a apenas $57 \%$ da renda urbana nacional. 
Para efeito analítico, é possível distinguir, dentro do espaço urbano regional, o Nordeste metropolitano e o náo-metropolitano. O primeiro, integrado pelas aglomerações de Fortaleza, do Recife e de Salvador, com $\mathbf{5 \%}$ da população do país e $7 \%$ da urbana, tem participação nas rendas total e urbana nacionais de $4,9 \%$ e $5,5 \%$, respectivamente - e, em decorrência, sua renda per capita equivale a $95 \%$ e $78 \%$, respectivamente, das rendas nacionais total e urbana. O segundo, com $12 \%$ da população nacional total e $16 \%$ da urbana, detém somente $6,7 \%$ e $7,4 \%$ das rendas nacionais correspondentes - e, portanto, sua renda per capita equivale a $58 \%$ e $\mathbf{4 8 \%}$ das rendas total e urbana brasileiras.

É de 9,1 milhóes o número de pobres do Nordeste urbano (53), o que representa $23 \%$ da pobreza total do país e $48 \%$ da urbana. Desse total, 2,2 milhões (24\%) vivem nas três regiốes metropolitanas regionais (Fortaleza: 735 mil pobres; Recife: 895 mil; Salvador: 574 mil) e os restantes $76 \%$ (6,9 milhóes) habitam as demais cidades, vilas e áreas urbanas isoladas (54). A incidência de pobreza, de $38 \%$ para o meio urbano regional como um todo, é de $29 \%$ para as regiốes metropolitanas e de $41 \%$ para o Nordeste urbano não-metropolitano.

A despeito da grande diversidade de situações sociais encontrada no Nordeste urbano, algumas das principais características da pobreza que lá vive apresentam, em alguns aspectos essenciais, certa homogeneidade.

Com efeito, a renda familiar per capita anual dos pobres urbanos da região é de US\$231, a dos metropolitanos, US\$234, e a dos urbanos não-metropolitanos, US\$ 230; os números médios de pessoas por família são de 4,6, 4,6 e 4,7, respectivamente; e os percentuais de crianças (0-14 anos) freqüentando a escola são de $80 \%, 83 \%$ e $79 \%$.

Outros indicadores, contudo, relativos às disparidades internas de renda, às condições de trabalho e à disponibilidade de alguns serviços e equipamentos domiciliares, revelam consideráveis discrepâncias entre o Nordeste metropolitano e o urbano não-metropolitano.

Assim é que, nas metrópoles regionais, a parcela da renda familiar total detida pelos pobres é de apenas $4 \%$, comparados com $9 \%$ no meio urbano nãometropolitano, determinando renda familiar per capita dos não-pobres dez vezes superior à dos pobres no primeiro caso, e sete vezes no segundo.

Por outro lado, indicadores como o percentual de trabalhadores pobres com carteira assinada (52\% nas metrópoles e $37 \%$ no restante do meio urbano), o percentual de ocupados por conta própria contribuintes da previdência social (9\% e 5\%, respectivamente), as disponibilidades domiciliares de água com canalização interna ( $52 \%$ e $43 \%$ dos domićlios) e de geladeira ( $51 \%$ e $33 \%$ ) de- 
monstram que as condiçôes de vida dos pobres metropolitanos são melhores do que a dos demais pobres urbanos. Isto revela que muitos dos serviços sociais públicos na regiáo se distribuem desigualmente entre os pobres no espaço urbano, beneficiando mais as populaçóes metropolitanas.

A pobreza urbana do Nordeste reduziu-se significativamente nos anos $70 \mathrm{em}$ decorrência do crescimento econômico, ainda que em menor grau do que a do Sudeste metropolitano. Entre o início e o fim daquela década, enquanto a renda urbana per capita crescia $65 \%$ (5,1\% ao ano), a pobreza se reduzia tanto em termos absolutos (de 6,2 para 5,6 milhóes) quanto, sobretudo, em termos relativos (de $60 \%$ para $33 \%$ da população) (55). Esse fato torna-se ainda mais relevante quando se considera que a população urbana regional cresceu $49 \%$ naquela década, ou seja, $4,1 \%$ ao ano, o que se deve em grande medida às migraçóes rurais (estimadas em 2,9 milhóes) (56), que explicam a metade desse crescimento.

Em contrapartida, na década de 1980 , concomitantemente à queda da renda per capita urbana da ordem de $15 \%$, ocorreu aumento importante da pobreza urbana (de $63 \%$, em termos absolutos, e de $33 \%$ da população urbana para os $38 \%$ já referidos), com a ausência de dinamismo econômico bloqueando a inserção dos pobres em mercado de trabalho estagnado, ampliando-se, assim, tanto o desemprego quanto o subemprego.

Algumas das características dos chefes de família pobres do Nordeste urbano complementam, em alguns aspectos significativos, a análise empreendida até aqui (57).

Com efeito, a renda familiar dos pobres depende, em $71 \%$, do trabalho de chefes de família, que têm em média 3,6 dependentes, dos quais apenas 1,2 com menos de 15 anos. Portanto, 2,4 pessoas por família, já em idade ativa, geram somente $29 \%$ da renda familiar. Embora esse último percentual seja maior do que o do meio rural pobre da regiáo $(24 \%$, para 2,9 pessoas por família em idade ativa), é sabido que as possibilidades de intensificação do uso independente do trabalho familiar são relativamente maiores no meio urbano regional do que no rural (58).

O percentual de famílias chefiadas por mulheres é de $31 \%$ (23\% para as não-pobres), com a região metropolitana de Salvador alcançando o percentual de $38 \%$ (24\% para as não-pobres). Esses valores, muito maiores do que os encontrados no meio rural (Brasil: pobres, $14 \%$; não-pobres, $13 \%$; Nordeste: pobres, $15 \%$; não-pobres, $17 \%$ ) sugerem que, também no Nordeste, o processo de desagregação da família é muito mais intenso no meio urbano, particularmente entre os pobres. Dentre as demais famílias consideradas como potencialmente vulneráveis incluem-se as chefiadas por menores de 18 anos (1\%) ou maiores de 60 anos $(17 \%)$, bem como por pessoas de cor preta. 
Com respeito à cor, observe-se que os chefes de família pobres pretos $(8,1 \%)$ e pardos $(68,3 \%)$ são proporcionalmente mais numerosos do que os não-pobres (5,2\% de pretos e $59,1 \%$ de pardos), chegando eles em Salvador a $90,1 \%$ do total de pobres (28,6\% de pretos e $61,5 \%$ de pardos, comparados com $13,6 \%$ e $56,4 \%$, respectivamente, para os não-pobres). Estabelece-se, assim, no meio urbano do Nordeste, tendência que associa, muito mais fortemente do que no meio rural regional ou no Sudeste metropolitano como um todo, cor e pobreza (59).

Parcela significativa dos chefes de família pobres do Nordeste urbano (21\%) vive da agricultura: como o mesmo não ocorre no subconjunto metropolitano, onde apenas $7 \%$ vivem de atividades agrícolas, é de esperar-se que o fenômeno ocorra mais nas pequenas e médias cidades e vilas, em muitos aspectos um prolongamento da vida rural. Um terço deles trabalha em outras atividades que em geral também apresentam baixa produtividade: construção civil (13\%) e serviços informais (20\%). Os restantes $46 \%$ trabalham no comércio (14\%), na indústria de transformação (12\%) e em outras atividades (20\%). Entre os empregados, $31 \%$ não possuem carteira assinada. Entre os ocupados, $34 \%$ trabalham por conta própria.

Os níveis educacionais dos chefes de família pobres são alarmantemente baixos no meio urbano do Nordeste: $47 \%$ são analfabetos, $34 \%$ têm quatro anos, ou menos, de escolaridade, e apenas $19 \%$ possuem cinco anos, ou mais, de escolaridade. Esse quadro educacional melhora um pouco apenas no Recife e em Salvador, com o percentual de analfabetos reduzindo-se para $35 \%$ e $26 \%$, respectivamente, e a parcela dos que têm cinco anos ou mais de instrução elevando-se para $30 \%$ e $39 \%(60)$.

Os níveis de subeducação da população ativa do Nordeste como um todo atuaram decisivamente, tanto para determinar desconcertante segmentaçáo do mercado de trabalho urbano e agravar a desigualdade quanto para impedir, nas décadas de 1970 e 1980, maior crescimento relativo da renda dos pobres e sua mais ampla inserção na economia organizada em expansão. Com efeito, a participação dos $40 \%$ mais pobres na renda regional reduziu-se de $8,8 \%$ em 1970 para $8,5 \% \mathrm{em} 1980$ e $7,8 \%$ em fins dessa última década. $\mathrm{E}$ a renda das pessoas ocupadas, maiores de vinte anos e com cinco anos ou mais de escolaridade, sendo equivalente à do total das pessoas ocupadas nessa faixa etária em 1970, já era 50\% maior em 1980 e alcançou quase o dobro em fins desse decênio. É esta uma clara evidência da importância da educação fundamental na determinação do nível de renda individual na região, fenômeno que é mais relevante no meio urbano.

O pobre do Nordeste urbano não é o mesmo pobre do meio rural da regiāo. Não é, tampouco, o pobre do Sudeste metropolitano. O seu ser pobre situa- 
se, por assim dizer, entre uma e outra dessas pobrezas: ele participa de suas duas naturezas, distanciando-se, entretanto, tanto duma quanto doutra.

Duas características o aproximam dos pobres rurais nordestinos. Duas outras mimetizam as situações de pobreza do Sudeste metropolitano.

A primeira indica, conforme já se observou, que é alta nas cidades a incidência de pobreza (38\%). Note-se agora que essa incidência sofre uma gradação: é menor nos núcleos das três regiốes metropolitanas (24\%), aumenta em suas periferias (35\%) e se torna mais grave nos outros centros urbanos (42\%) (61). Quando se considera, entretanto, que esse percentual, para as cidades regionais como um todo, embora se tenha reduzido em períodos de crescimento econômico, nunca foi inferior a $1 / 3$, conclui-se que a base econômica do Nordeste urbano não se tem revelado suficiente para absorver produtivamente seu contingente de pobres, que aumentou em 2,9 milhões na década passada.

A segunda característica ressalta que a pobreza urbana regional é alimentada, em grande medida, pelas migraçóes internas rural-urbanas, que transportam para as cidades, e nelas propagam, formas de sentir, pensar e agir dominantemente pré-modernas. Os migrantes pobres se assentam nas periferias urbanas (comumente nos alagados e morros das grandes cidades litorâneas), ali misturando-se à pobreza gerada nas cidades. Assim reduzindo, pela própria dimensão que esse contingente de pobreza adquire, as possibilidades, já limitadas, de inserção econômica e de ascensão social.

A terceira característica revela que, como nas metrópoles do Sudeste, não se encontram os pobres urbanos do Nordeste segregados da sociedade envolvente. Eles convivem com a cidade, sendo afetados pelos eflúvios da modernidade, que confundem suas visôes do mundo sem, contudo, alterar significativamente as condições objetivas de acesso às benesses do progresso. Pois mais uma vez é a dimensão excessiva dos pobres, relativamente aos não-pobres, que impede a formação de teia de relações de complementaridade entre eles com a abrangência e o significado da que se observou no Sudeste metropolitano.

A quarta característica traz de volta a questão do homem marginal versus homem integrado, que se examinou quando da análise das três metrópoles nacionais. No caso do Nordeste urbano (inclusive do metropolitano), o pêndulo pende relativamente mais para a marginalização do que para a integração (62). A esse respeito, os dados anteriormente apresentados indicam que a pobreza urbana do Nordeste não possui as habilidades básicas para que sua inserção nas cidades lhe promova a desejada ascensão social. Se pode haver inapetência dos pobres para adquiri-las, é fato, no entanto, que a oferta pública dos equipamentos e serviços que propiciariam a aquisição dessas habilidades (em particular os educa- 
cionais e de qualificação para o trabalho) é ali mais escassa e de menor qualidade justamente nas áreas de concentração de pobreza. E se há, da parte deles, alguma desconfiança quanto à utilidade desse aprendizado, essa insuficiência dos serviços do Estado decerto contribui para inibir suas iniciativas de integração, além de mantê-los desigualados na disputa pelas poucas oportunidades de emprego e de participação na renda proporcionadas pela economia.

O que se pode, em síntese, dizer do pobre que vive nas cidades do Nordeste é que ele se situa, psicossocialmente, em transição do rural para o urbano. Seria ele um homem rurbano (63), seja intra-subjetivamente, seja nas atitudes que sua conduta objetivamente manifesta. Se o seu drama maior é a própria pobreza, essa ambigüidade existencial, além de limitar suas chances de superá-la, acarreta-lhe distúrbios de percepção, desvios de comportamento, acúmulos de frustraçóes, tão psiquicamente traumáticos quanto socialmente tensivos.

\section{Combatendo a pobreza I: variáveis e ações estratégicas}

Verificou-se, na análise interpretativa das situações de pobreza empreendida anteriormente, que existe forte correspondência, em especial no meio urbano, entre crescimento econômico sustentado e redução da pobreza. Observou-se também que há formas variadas de relacionamento, geralmente refletindo complementaridade e interdependência, entre pobres e não-pobres.

Essas duas constatações sugerem que as intervenções públicas em situações de pobreza náo devem considerá-las isoladamente da sociedade envolvente, nem serem vistas de modo estático, sendo, ao contrário, necessário contextualizá-las, a partir da seleção das variáveis que, na dinâmica do desenvolvimento: produzem mais renda e riqueza; afetam sua distribuição social, em particular entre pobres e não-pobres; e operam o engate entre a primeira e a segunda. As duas variáveis que sobressaem nesse contexto são o crescimento e o conhecimento. $O$ engate entre elas dá-se pragmaticamente através da variável trabalho. Crescimento, conhecimento e trabalho constituem as variáveis estratégicas que integram o núcleo comum dos modelos de intervenção propostos, embora as açóes estratégicas decorrentes variem consideravelmente de uma situação social para outra.

\section{Crescimento: beneficiando a pobreza}

Se não há nada de novo ou surpreendente na escolha do crescimento econômico como variável estratégica no combate à pobreza, são grandes e diferenciadas suas implicações na concepção de modelos de intervenção delineados neste estudo. 
Por um lado, não se deve dissociar nesses modelos política econômica de política social (64). Não há crescimento socialmente neutro: ele gera renda e acumula riqueza, que são socialmente apropriadas. Nesse sentido, as açóes públicas antipobreza precisam estar explicitamente consideradas na formulação e execução das políticas econômicas - e não meramente de forma apendicular e subsidiária, ou apenas como medidas compensatórias -, pois se, de uma parte, os investimentos destinados a reduzir a pobreza podem afetar, positiva ou negativamente, o ritmo do crescimento, este é, sem dúvida, crucial arma em seu combate.

Um simples exercício hipotético seria eloqüentemente ilustrativo dessa última inter-relação. Com efeito, crescimento da renda familiar per capita total (de pobres e não-pobres) do Sudeste metropolitano de apenas $0,7 \%$, que fosse apropriado inteiramente pelos pobres, seria suficiente para elevar sua renda média acima da linha de pobreza adotada neste estudo. Para obter-se o mesmo efeito no Nordeste urbano, seria necessário crescimento de $5,7 \%$; e, no Nordeste rural, de $34,4 \%(65)$.

Embora se saiba que a apropriação de todo o produto do crescimento pelos pobres não é factível - inclusive em decorrência das relaçóes de complementaridade econômica entre pobires e não-pobres antes referidas, com efeitos na determinação da renda dos primeiros -, fica demonstrado que uma maior participação dos pobres nos resultados do crescimento é estratégia que se deve privilegiar por sua irrecusável eficácia.

Por outro lado, são bastante diferenciados os efeitos do crescimento como mecanismo de transmissão espontânea de renda dos não-pobres para os pobres. Recorde-se que a análise das três situações sociais antes empreendida fortemente sugeriu produzirem-se nelas impactos diversos do crescimento na reduçáo da pobreza: de intensidade alta no Sudeste metropolitano, média no Nordeste urbano (média-alta nas metrópoles regionais e média-baixa no meio urbano não-metropolitano) e baixa no Nordeste rural. É que, num extremo, o pobre do Nordeste agrário, além de majoritário (constituindo mais de $2 / 3$ da população), inserese em economia globalmente muito pobre e fragilmente estruturada, além de achar-se defendido dos estímulos de mercado e imerso em invólucro cultural pouco permeável. No outro extremo, o pobre das metrópoles nacionais, minoritário (formando menos de $10 \%$ dos habitantes), encontra-se mais integrado em economia muito mais rica, complexa e solicitante, e em sociedade polimorfa e fortemente interligada. No meio situa-se o Nordeste urbano, com seus pequenos núcleos urbanos aproximando-se do primeiro extremo e as regióes metropolitanas, do segundo.

No Sudeste metropolitano, portanto, o crescimento da economia organizada transbordará mais facilmente para os pobres, contribuindo para reduzir a 
pobreza (embora possa estimular novas imigraçóes de pobreza, do meio rural e de outras cidades). No Nordeste rural, ao contrário, crescimento da agricultura que se assente em bases empresariais modernas será incapaz de incorporar, em níveis significativos, o grande contingente de pobres que ali vive, podendo reduzir ainda mais a capacidade de retenção da população no campo, impulsionando a emigração. No Nordeste urbano, embora seja importante buscar no reforço da base econômica moderna fontes mais dinâmicas de expansão produtiva, essa seqüência de crescimento dificilmente será suficiente, a médio e mesmo longo prazos, para absorver amplamente a pobreza (sobretudo se persistirem as imigraçóes de origem rural).

Isto significa que a estratégia econômica para o Nordeste, tanto urbano quanto rural, deve ter, como um de seus componentes essenciais, a incorporação da pobreza à produção e ao consumo, o que é, efetivamente, condição para a própria viabilidade de crescimento que pretenda ser sustentado e que em parte se apóie em mercado interno regional em expansão. Pois, mesmo desconsiderando o objetivo eqüidade, é difícil imaginar crescimento sustentado em região, de razoável dimensão (mais de 40 milhões de habitantes e PIB de cerca de US\$ 60 bilhões anuais), que por muito tempo mantenha a metade de sua populaçáo economicamente excluída de seus benefícios.

Esse processo de gradual inclusão somente ocorrerá mediante estratégia de crescimento que combine o upgrade dos recursos humanos da população pobre com a criação de oportunidades de sua efetiva utilização produtiva.

\section{Conbecimento: estendendo a educação e a qualificação aos pobres}

Um dos fatores que reconhecidamente mais afeta a expansão e a distribuição social da renda e da riqueza é o conhecimento, que se incorpora aos indivíduos sob a forma de capital humano.

Sabe-se, de um lado, que o domínio e a aplicação do conhecimento na economia e, em geral, na sociedade importam, mais e mais, à riqueza das naçóes. Sabe-se, de outro, que em cada uma delas também é crescente sua influência na repartição inter-regional e interpessoal da renda. Habilitar os pobres a maior participação na expansão do produto social implica, portanto, elevar seus níveis de conhecimento através da educação e da qualificação para o trabalho, de modo a capacitá-los a inserção na economia que lhes assegure, como requisito mínimo, a satisfação das necessidades básicas.

Releva, no contexto do objetivo mais amplo de universalização da educação básica, que as populaçóes pobres sejam alcançadas pelo que se poderia chamar de esforço de formação de mentalidade moderna. 
Não se postula, é claro, uma escola para a criança ou o adolescente pobres diferente da escola para os não-pobres. $O$ que se deseja é que a escola, nas áreas urbanas e rurais de concentração de pobreza, atenda a padróes mínimos de qualidade (envolvendo capacitação docente, instalações e equipamentos, conteúdo programático, métodos de ensino-aprendizado, formas eficientes de gestão e de avaliação de resultados). Que seja uma instância inoculadora de modernidade em interação com o mundo do trabalho e as vivências do cotidiano. Que, enquanto tal, ensine a pensar logicamente e a agir estrategicamente, estimulando o raciocínio, $o$ comando da linguagem, a autonomia crítica, a experimentação. Que torne irreversível a capacidade de auto-aprendizado e enseje a qualificação profissional (66).

Porém se vê como igualmente necessária uma ação educativa específica, de caráter supletivo, voltada para a população pobre já em idade ativa, em particular no Nordeste (tendo em vista os baixos níveis de escolaridade ali prevalecentes). Ação esta acoplada a formação profissional que propicie inserção mais produtiva na economia.

Se a escola regular, ao ministrar às crianças e adolescentes o ensino fundamental, deve estar atenta, sem prejuízo da homogeneidade imprescindível, às variadas situaçōes de pobreza, o ensino supletivo e a qualificação para o trabalho devem ver essas diferenciaçóes como essenciais a sua pertinência e eficácia. Aqui o objetivo primordial é capacitar adultos pobres, de forma compacta, ordenada e concentrada, para a vida em sociedade crescentemente complexa e para o trabalho mais produtivo em atividades tão diversas como a pequena agricultura de base familiar e a indústria de transformação praticando novas e mais participativas relações de trabalho.

\section{Trabalho: elevando a renda dos pobres}

O trabalho deve operacionalizar o enlace entre o conhecimento e o crescimento de que resulte, para o pobre, maior participação na produção e na renda (67).

As precondições necessárias desse enlace são, de um lado, a capacidade da economia de gerar, com o crescimento, oportunidades de trabalho capazes de ser apropriadas pelos pobres; do outro, o êxito dos esforços de suplementação educativa e de qualificação dos adultos (no curto-médio prazo) e de educação básica e formação profissional das crianças e adolescentes pobres (no médiolongo prazo).

Um olhar sobre os países mais desenvolvidos, que já avançaram em sua transformação produtiva, não inspira entusiasmo sobre a capacidade de geração 
de postos de trabalho pela economia urbana brasileira, já de algum tempo em processo de reestruturação industrial e de inserção internacional competitiva mormente quando se prevê, na presente década, demanda por 2,4 milhōes de novos empregos no Sudeste metropolitano e três milhóes no Nordeste urbano, apenas como decorrência do crescimento demográfico vegetativo (68). Contudo, cabe considerar que o processo de modernização produtiva será desigual espacial e setorialmente, além de, em geral, pouco intenso nas atividades que não enfrentam a concorrência das importaçóes ou não se voltam para o mercado externo (agricultura de subsistência, comércio, grande parte dos demais serviços, construção civil, utilidades públicas, pequenas empresas). E é nessas atividades que a absorção produtiva dos pobres poderá ser mais facilmente realizada, inclusive por serem elas geradoras de empregos ainda pouco exigentes em capital humano.

Nas regióes metropolitanas do Sudeste as ações públicas propiciadoras de emprego aos pobres devem centrar-se - a partir de educação supletiva e qualificação técnica, restritas (pelo menos num primeiro estágio) ao essencial para vencer as limitaçóes da sub-renda - na intermediação no mercado de trabalho e na a organização mais racional dos serviços prestados por conta própria. Pois é na aplicação de mais conhecimento em trabalho mais produtivo e, por isso mesmo, mais remunerador que reside o cerne de uma inserção econômica superadora da condição de pobreza (69).

No Nordeste urbano as linhas de ação acima mencionadas aplicam-se às regiôes metropolitanas e às maiores cidades, porém a dimensão da pobreza nelas existente aconselha a identificação de outras atividades menos dependentes dos estreitos mercados de trabalho locais e mais autônomas com respeito às limitadas demandas geradas internamente pelos não-pobres (70). $\mathrm{O}$ caso das pequenas cidades (numerosíssimas na região) é entretanto diverso. Muitas são meras projeçóes de economia rural depauperada e abrigam grande quantidade de pobres que vivem da agricultura. Elas freqüientemente se encontram em estado de letargia ou em franca regressão econômica e mesmo demográfica, apresentando grande incidência de subemprego. Identificar e viabilizar suas vocaçóes produtivas de modo a criar mais empregos, seja através de revitalização de suas bases agrícolas, seja mediante novas e mais dinâmicas interligações com os mercados regional e nacional (71), é o caminho para que os pobres possam nelas encontrar as chances de ascensão social.

No meio rural do Nordeste, embora se deva procurar reduzir o grau de dependência dos pobres da pequena agricultura, o que mais releva é transformála em atividade tecnicamente mais moderna e mais referida ao mercado (ainda que se preserve a unidade familiar de produção). Nesse contexto, é importante o acesso dos pobres a terras agricultáveis e de dimensões adequadas (seja mediante sua aquisição, seja mediante arrendamento de longo prazo); aos recursos hídricos 
indispensáveis (no semi-árido a pequena irrigação é condição necessária de garantia de renda mínima estável); e à eletrificação, ao crédito, à assistência técnica e às formas não espoliativas de comercialização (72). Inclusive para ampliar a capacidade de retenção demográfica no campo ao possibilitar aos pobres o uso dos fatores produtivos e a prática de tecnologias agrícolas mais avançadas e menos vulneráveis a fatores naturais adversos. Insiste-se, porém, mais uma vez, que essa transformação pressupóe uma nova postura do homem rural pobre perante $o$ mundo do trabalho que seja capaz de vencer as barreiras culturais que dificultam a racionalização de seu esforço produtivo (73). Isto envolve um processo de esclarecimento pedagogicamente complexo. Seu objetivo é o mesmo da educação supletiva e da qualificação técnica, já referido: a formação de mentalidade moderna, que na verdade equivale a aquisição de uma nova cultura. No Nordeste rural, porém, ela deve sobrepor-se criticamente a formas de pensar e agir profundamente arraigadas, cujo rationale determina o comportamento rotineiro e pouco empreendedor do pobre rural no trabalho. Essa atitude atávica está sendo cada vez mais desafiada pelos fatos e circunstâncias de seu próprio cotidiano. Por isso serlhe-á, talvez, mais fácil mudá-la. Seria, entretanto, ilusório pensar que ela será superada sem intenso reaprendizado do mundo, alcançado concomitantemente com organização racional da produção, de tal forma que possam gerar-se desse encontro as sinergias que ensejem o pobre a transpor o umbral a partir do qual o processo de sua ascensão social se tornará irreversível (74).

\section{Combatendo a pobreza II: ações complementares}

A partir do núcleo das ações antipobreza, concebido, algumas ações complementares, depreendidas da análise interpretativa das situações sociais examinadas, complementam os modelos de intervenção propostos, conferindo-lhes maior especificidade. Essas ações contemplam (75):

- a focalização nos pobres das politicas sociais priblicas de caráter setorial;

- o planejamento familiar;

- a intensificação do uso do trabalho como forma de complementação de renda;

- a assistência aos pobres mais pulneráveis, e a universalização da cidadania.

\section{Políticas sociais: a pobreza como público-alvo}

Já se observou que as políticas sociais públicas de natureza setorial, sendo em geral de extensão insuficiente, descontínua e precária nas áreas de concentração de pobreza, distribuem-se desigualmente entre elas, numa gradação em que as metrópoles do Sudeste são mais beneficiadas do que o Nordeste metropolitano, este último é melhor atendido do que o Nordeste urbano não-metropolitano, com o Nordeste rural delas recebendo a menor atenção. Esse fato em grande 
parte explica por que os diferenciais de níveis de vida médios entre os pobres dessas regióes sáo muito mais elevados do que os relativos a suas rendasper capita.

Impõe-se, portanto, prioridade diferenciada às populações pobres nas açóes sociais públicas em setores como saúde, habitaçáo e saneamento básico, relaçóes de trabalho, previdência e assistência social - além, evidentemente, da educação básica e supletiva e da qualificação para o trabalho, conforme já amplamente enfatizado. Os hiatos entre os níveis de vida e de renda podem reduzir-se importantemente, no Nordeste rural, urbano e metropolitano, mediante esforço governamental de ampliação da oferta e da qualidade desses serviços e seu direcionamento aos pobres (76).

Além de desempenharem importante papel na igualação de oportunidades, a incorporação dos pobres como beneficiários dessas açóes públicas tem, no meio rural e nas menores cidades do Nordeste, efeitos adicionais: o de reduzir os estímulos às migrações para as grandes cidades e o de influenciar, via mudanças nas condições de vida, percepções, atitudes e condutas individuais mais consentâneas com a modernidade.

A execução dessas políricas sociais, além de focalizadas nos pobres, deve ser descentralizada, envolvendo, na esfera pública, os estados e municípios e, na esfera privada, as próprias comunidades beneficiadas. A pouca eficiência dos gastos sociais públicos no Brasil em parte decorre de excessiva centralização, envolvendo complexos e custosos aparatos burocráticos e, em parte, é devida à incapacidade gerencial das entidades governamentais envolvidas e sua relutância em confiar às comunidades tarefas que elas podem exercer muito melhor e a menores custos (77).

\section{Planejamento familiar: dimensão da liberdade}

Ainda que se deva propiciar a todos os pobres, como uma das dimensóes do exercício de sua liberdade, as informaçóes e os meios para o planejamento familiar responsável, uma atuação pública orientada por esse propósito justificase particularmente no Nordeste rural (e, embora em menor grau, nas pequenas cidades dessa região).

Recorde-se que as famílias do Nordeste rural (com em média 5,3 membros) são relativamente mais numerosas, e que seu tamanho vem se reduzindo mais lentamente com relação seja às urbanas, seja às metropolitanas (78). A adoção na região de política bem-orientada de planejamento familiar com liberdade parece impor-se, pois, embora o uso da anticoncepção tenha se expandido a partir dos anos 60, as taxas de fecundidade continuam bastante elevadas (79). 


\section{Intensificação do uso do trabalho: outras fontes de renda}

A dependência familiar das rendas dos chefes de família pobres é um pouco maior do que a dos não-pobres em cada uma das situaçóes sociais examinadas neste estudo, a despeito de ser mais alto, nas famílias pobres, o número médio de pessoas dependentes em idade ativa. Adicionalmente, essa dependência se eleva, entre os pobres, no Nordeste rural, onde a subutilização da força de trabalho familiar seria maior, principalmente em função dos períodos de entressafra próprios da agricultura tradicional de subsistência.

O mais amplo emprego da força de trabalho familiar pode, portanto, constituir mecanismo de elevação da renda dos pobres. No Nordeste rural essa intensificação do uso do trabalho pode ocorrer com diversificação das atividades produtivas, hoje muito dependentes de agricultura comumente de alto risco: para o artesanato, o beneficiamento doméstico de produtos agrícolas, por exemplo.

\section{Assistência aos mais pulneráveis}

Por grupos sociais pobres potencialmente mais vulneráveis compreende-se aqui, de uma parte, o subgrupo das famílias chefiadas por mulheres, por pessoas do sexo masculino menores de 18 anos ou maiores de 60 anos, e por homens adultos (18-60 anos) de cor preta; de outra, o subgrupo (que em parte se sobrepóe ao primeiro) formado pelas crianças, gestantes e nutrizes, idosos e deficientes (80).

Este deve ser o público-alvo das políticas públicas antipobreza de caráter mais assistencial.

Não se entenda, entretanto, que essas ações devam adotar postura meramente assistencialista. Na maioria dos casos a assistência necessária deve estar acoplada à criação de oportunidades de autopromoção humana, pela educação e pelo trabalho. Isso é certamente possível para todo o primeiro subgrupo e para a grande maioria do segundo (excetuados os idosos e os gravemente deficientes, que devem ser atendidos pela previdência e assistência sociais).

\section{Cidadania: presença do Estado em áreas de pobreza}

Se freqüentemente se admite que o exercício pleno da cidadania pressupóe $o$ atendimento das necessidades básicas, dimensão essencial da liberdade, também é útil entender que, sendo o resultado de relações de reciprocidade entre $o$ indivíduo e o Estado, os direitos e deveres do cidadão não podem prescindir da presença eficaz do aparato técnico-burocrático governamental nos espaços econômico-sociais em que o homem vive e trabalha. 
É dessa presença do Estado como instância de poder e como agência de serviços que carecem as áreas urbanas e rurais de concentração de pobreza examinadas neste estudo - para que nelas se exercite melhor intercomunicaçáo cooperativa, entre povo e governo, de que devem resultar menos pobreza e mais cidadania.

Cabe a propósito referir que essa presença é hoje tão necessária nas metrópoles nacionais como nas cidades e no meio rural nordestinos. É na ausência do Estado (e, em muitos casos, sob o manto protetor de seus agentes, cooptados inclusive pelo suborno) que proliferam, nas favelas metropolitanas (em especial no Rio de Janeiro), os poderes paralelos associados ao crime organizado, que desafiam impunemente a ordem pública e subvertem os valores sobre os quais se assenta a sadia convivência social.

Enquanto esses quistos de marginalidade ameaçam alastrar-se nas grandes cidades, no meio rural e nos menores núcleos urbanos do Nordeste ainda subsistem, se bem que em regressão, as formas de domínio pré-estatais características do coronelismo.

Essas (e muitas outras) anomalias abertamente denunciam que o Estado brasileiro ainda não governa inteiramente o seu território. E que ele tampouco assegura a todos o que constitui dever essencial seu: a lei e a ordem, condiçóes necessárias, ainda que insuficientes, da liberdade do cidadão (81).

\section{Conclusão: estratégia de desenvolvimento e pobreza}

Conforme se observou na introdução deste estudo, há consenso quanto aos objetivos-fins do desenvolvimento. Não existe, entretanto, concordância sobre as estratégias a serem adotadas para que esses objetivos possam ser alcançados pelos países subdesenvolvidos ou em desenvolvimento.

É bem verdade que a débácle do chamado socialismo real restringiu o leque das opçóes estratégicas confrontadas pelos estados-nações. Elas, contudo, ainda ocupam um amplo espectro, porquanto dependem, entre outros fatores, do estágio de desenvolvimento atingido, das ênfases relativas conferidas aos objetivos eficiência, equiidade e liberdade, da divisão de trabalho entre as esferas pública e privada da sociedade, da capacidade política de obter convergência de diferenciados interesses e aspirações sociais.

As escolhas estratégicas de desenvolvimento pelos países menos avançados, portanto, são decisóes que ainda estão a requerer muita reflexão.

Acresce, ademais, que o ideário político tende a sobrecarregar essas estratégias com doses generosas de eqüidade e liberdade, voluntaristamente eleitas como 
objetivos de curto prazo, sem exame mais detido de suas condiçóes de viabilidade. Para evitar frustraçóes de expectativas, infelizmente tão freqüentes, seria útil ter sempre presente que os objetivos liberdade, eqüidade e eficiência impõem entre si limites muito precisos, embora variáveis no tempo e entre países. De modo geral, poder-se-ia, por exemplo, afirmar que uma social-democracia de padrão ocidental-europeu em um país com cerca de US\$ 3 mil anuais de PIB per capita poderia estar legitimamente impressa em seu ordenamento institucional, mas não terá, a curto, médio e mesmo longo prazos, condições de ser efetivamente praticada, tornando-se, assim, pragmaticamente vazia.

Acrescente-se ainda - e considerando agora basicamente a questão da eqüidade versus eficiência mais com o intuito de problematizá-la -, que uma opção por redistribuição interpessoal da renda (por exemplo pela via fiscal) pode repercutir sobre a trajetória de desenvolvimento de modo radicalmente diferente de uma opção pelo combate à pobreza.

A primeira dessas opções poderá ser eficaz em reduzir as desigualdades relativas de renda (o Coeficiente de Gini, por exemplo). Porém, ao alterar a estrutura de demanda, poderá desestabilizar o crescimento. E ela não assegura necessariamente a redução da pobreza (mesmo que se admita que o Estado seja eficiente na destinação, aos pobres, dos recursos tributários adicionais arrecadados, os quais, de resto, podem vir a reduzir-se grandemente pela resultante perda de dinamismo da economia). Ou seja, no frigir dos ovos pode-se muito bem ter redistribuição sem (ou com menos) crescimento e sem (ou com menos) redução da pobreza, o que não é o melhor dos mundos.

A segunda opção - combate à pobreza - também contém seus riscos. Eles se explicitam teoricamente no conhecido trade-off entre eficiência e eqüidade: os recursos destinados ao combate à pobreza poderiam ter alternativa de aplicação mais produtiva (por exemplo, na melhoria da infra-estrutura econômica), de que resultaria mais crescimento (e lembre-se que o crescimento pode espontaneamente atuar na redução da pobreza e constitui quase sempre precondição de sua viabilidade). Ademais, os efeitos de redução da pobreza sobre as desigualdades relativas de renda podem ser, pelo menos num primeiro estágio, muito pequenos.

Já se terá, porém, depreendido que neste estudo considera-se a opção pelo combate à pobreza como mais prioritária para os países subdesenvolvidos e em desenvolvimento porque ela apresenta maiores probabilidades de engendrar a seqüência virtuosa de progresso representada por mais crescimento, mais eqüidade e mais liberdade. A prioridade conferida a essa trajetória decorre do fato de que o não-atendimento das necessidades fundamentais de parcelas consideráveis da população é o maior desafio social e político desses países, o qual, enquanto não for resolvido, permanecerá como séria ameaça a seu desenvolvimento. E suas 
possibilidades de êxito são maiores porque a pobreza crítica é uma realidade social concreta, visível, delimitável, sendo, assim, mais fácil combatê-la, bem como porque se obtém mais facilmente consenso nacional de que é preciso erradicá-la ou, pelo menos, reduzi-la.

A última questão a considerar nesta conclusão é a que diz respeito à aplicabilidade dos modelos de ação antipobreza, esboçados neste estudo a partir do desenho de três diferentes perfis de pobreza rural e urbana no Brasil, a outros países.

O que parece sensato defender é que o seu arcabouço básico teria validade geral, devendo, entretanto, ser adaptado às peculiaridades de cada situação social.

Afinal, uma das teses centrais apresentadas neste estudo é a da grande diversidade de características das condiçóes de pobre. E são dois os seus corolários. O primeiro é que cada situação de pobreza comporta intervenção específica, a ela adequada, o que é condição para sua efetividade. E, o segundo, a necessidade de descentralizar a execução das ações antipobreza - como participação ativa, nelas, dos próprios pobres -, o caminho mais eficaz para que essas peculiaridades sejam realmente levadas em conta.

De todo modo, resultaria mais ou menos óbvio que o Nordeste rural brasileiro - um caso de subdesenvolvimento onde os pobres enfrentam bloqueios culturais à racionalidade econômica e obstáculos de acesso aos fatores de produção e ao mercado - guardaria similitudes, por exemplo, com o dos países da África subsaariana, onde, de resto, as interdições, de origem tribal, à modernidade seriam ainda mais resistentes. Na outra ponta, o Sudeste metropolitano - um caso de grandes aglomeraçóes urbano-industriais que, entretanto, ainda abrigam importantes contingentes de pobres vivenciando graus diferenciados de integração econômica, social e cultural - seria semelhante ao das grandes cidades do mundo em desenvolvimento, como as dos maiores países da América Latina e do Leste asiático e Pacífico. No meio, o Nordeste urbano - um caso de pobreza decorrente de urbanização demograficamente excessiva com relação à base econômica, em grande medida gerada por migraçóes rural-urbanas - aproximar-se-ia de situações de pobreza prevalecentes no Oriente Médio, no Norte da África e nos menores países das Américas.

\section{Notas}

1 Veja-se, a propósito, do autor deste estudo, Opções de desenvolvimento e estratégia social: concepção geral, in João Paulo dos Reis Velloso (coord.), Estratégia social e desenvolvimento, 'Rio de Janeiro, José Olympio, 1992, p. 29-71. 
2 A redução do desenvolvimento ao crescimento da produção - um viés economicista - tem conduzido à simplificação que consiste em tomar o PIB per capita como medida do desenvolvimento. Retomam-se, nos últimos anos, as tentativas de construir indicadores mais abrangentes, sintéticos ou agregados, de que é exemplo o IDH f́ndice de Desenvolvimento Humano. Cf. United Nations Development Programme Undp, Human development reports, 1990-3, New York, Oxford Univ. Press, 1990-93. Exemplo de índice global de desenvolvimento construído para o Brasil, suas regióes e estados encontra-se em Roberto Cavalcanti de Albuquerque (coord.), $O$ Brasil social: realidades, desafios, opfóes, Rio de Janeiro, Ipea, 1993, p.281-414.

3 Como sabido, o Coeficiente de Gini é índice que, variando de zero a um, expressa em que medida uma determinada distribuiçáo interpessoal de renda se aproxima da igualdade absoluta (quando o Coeficiente é igual a zero) ou da desigualdade absoluta (quando é igual a um). O Brasil, com Coeficiente de Gini de 0,57 , apresenta, de acordo com esse indicador, um dos mais elevados graus de desigualdade dentre 28 países considerados pelo Undp (1975-88). Cf. Undp, Human depelopment report 1992, cit., p. 160-161.

4 O Human development report 1992, cit. (p.26-33), intenta construir, para 104 países, um indicador agregado de liberdade política, o ILP - Índice de Liberdade Política, expresso em percentuais. A conclusão geral é que os países mais desenvolvidos têm um ILP mais elevado (de 90\%, em média) do que os menos desenvolvidos (ILP médio de 51\%), com os 104 países apresentando ILP médio de 61\%. Em O Brasil social, cit., incursiona-se nesse terreno, ainda pedregoso, da politicometria (loc. cit. esp. p. 423-443).

5 São eles fundamentalmente os países membros da Organização para Cooperaçâo e Desenvolvimento Econômico (Ocde), com exceção da Turquia. Cf. The World Bank, World development report 1993, esp. p. xi e 345.

6 O conceito de modernidade tríplice vem sendo utilizado por João Paulo dos Reis Velloso, principalmente em Inovafã̃o e sociedade: uma estratégia de desenvolvimento cage equiidade para o Brasil,' Rio de Janeiro, José Olympio, 1994.

7 O Banco Mundial classifica os países, segundo esse critério, em economias de alta renda (PIB per capita anual de US\$ 7.911 ou mais), de renda média alta (US\$ 2.5567.910), renda média baixa (US\$ 636-2.555) e baixa renda (US\$ 635 ou menos). $O$ Brasil está classificado no grupo de renda média alta (PIB per capita de US\$ 2.940, em 1991). Cf. World development report 1993, p.344-345 e 253.

8 São aqui considerados como países subdesenvolvidos as economias de renda baixa. Cf. nota 7, supra.

9 Os Coeficientes de Gini para esses países variam bastante: desde 0,62 (Honduras) até 0,34 (Bangladesh). A incidência média de pobreza crítica (ou absoluta) é, entretanto, muito elevada (62\% da população, em média) e o Índice de Liberdade Política (ILP), de apenas 48\%. Cf. Human development reports 1992-93, cit. 
10 Países de renda média baixa e alta (ver nota 7 , supra).

11 Os países em desenvolvimento apresentam Coeficientes de Gini que variam de 0,31 (Indonésia) a 0,66 (Jamaica). As incidências de pobreza crítica também são bastante diversas: vão de $17 \%$ da população (Tunísia) a $58 \%$ (Indonésia), situando-se, em média, em $25 \%$. O ILP, para esses países, de $50 \%$, é muito pouco superior ao dos países subdesenvolvidos. Cf. Human development reports 1992-93, cit.

12 Trata-se de pobreza crítica (ou absoluta), entendida como a condição sócio-familiar na qual as necessidades básicas não estão atendidas. Pobres são neste estudo consideradas aquelas pessoas cujo rendimento familiar per capita é igual ou inferior a $1 / 4$ do salário mínimo vigente em 1980 (valor esse correspondente a US\$ 35 mensais, ou a US\$ 417 anuais - dólares de 1990). Cf. Albuquerque, Roberto Cavalcanti de. Pobreza e exclusão social. In: Velloso \& Albuquerque, Pobreza e mobilidade social, São Paulo, Nobel, 1993, p. 53-102. Admitida a mesma incidência de pobreza (27\%), os pobres no país seriam, em 1994, 41,2 milhōes (população estimada para 1994: 152,8 milhōes).

13 A distância social é medida pelo quociente das rendas familiares per capita dos nãopobres e dos pobres. Cf. Pobreza e exclusão social, cit.

14 Para os efeitos desta análise foram examinadas as situações de pobreza correspondentes aos meios rural e urbano das macrorregióes brasileiras - Norte (somente o meio urbano), Nordeste, Sudeste, Sul e Centro-Oeste -, bem como as nove regiōes metropolitanas do país (Belém, Fortaleza, Recife, Salvador, Belo Horizonte, Rio de Janeiro, São Paulo, Curitiba e Porto Alegre): ao todo, dezenove situaçóes. As rendas familiares per capita dos pobres variam, entre essas situações, apenas $18 \%$ em torno da média nacional (US\$ 225 anuais). Entretanto, indicador agregado que mensura o grau de atendimento relativo das necessidades básicas de pobres e de não-pobres do país (o ICB - Índice de Carências Básicas), que varia entre 100 (muito baixo atendimento) e 900 (atendimento muito alto) apresenta considerável variação entre os pobres (num extremo, o ICB dos pobres do Nordeste rural é de apenas $105 \mathrm{e}$, no outro, o de Belo Horizonte é de 499). Cf. Pobreza e exclusão social, cit.

15 Cf., por exemplo, Bonelli, Regis \& Sedlacek, Guilherme Luís, Distribuição de renda: evolução no último quarto de século, in Sedlacek, G.L. \& Paes de Barros, R. (eds.), Mercado de trabalho e distribuição de renda: uma coletanea, Rio de Janeiro, Ipea, 1989, p. 7-24.

16 Veja-se Bonelli \& Sedlacek, cit.

17 Cf. Albuquerque, R.C. de \& Villela, R., A situação social no Brasil: um balanço de duas décadas, in $A$ questão social no Brasil, cit., p. 23-104. Veja-se, tamberm, Castro, A. Barros de, O Brasil a caminho do mercado de consumo de massa, in Velloso, J.P. dos Reis, As perspectivas do Brasil e o nopo governo, São Paulo, Nobel, 1990, p. 121 126. Esses trabalhos foram apresentados no Fórum Nacional, reunião anual de economistas, cientistas sociais e políticos e lideranças representativas da sociedade, realizada sob os auspícios do Instituto Nacional de Altos Estudos (Inae), do Rio de Janeiro. 
18 Programa de Desenvolvimento de Áreas Integradas do Nordeste. A concepção original do Polonordeste, formulada pelo Instituto de Pesquisa Económica Aplicada Ipea a partir do conceito de áreas integradas, espacialmente descontínuas, foi adotada, em 1974, pelo II PND [Cf. República Federativa do Brasil. II Plano Nacional de Desenvolvimento - II PND (1975-1979). Brasília, 1974, esp. p. 62-64]. Sob a influência do Banco Mundial, foi posteriormente utilizado o conceito de projetos de desenvolvimento rural integrado (PDRIs). Veja-se, a propósito, Albuquerque, Roberto Cavalcanti de. Polonordeste: o esforço de planejamento. Boletim Económico, Ipea, n. 4, jul./ago. 1976, p. 3-15.

19 Mutatis mutandis, no sentido dado à expressão por Rosenstein-Rodan, Paul, em Notes on the theory of the big push. In: Ellis, H.S. \& Wallich, H.C. (eds.), Economic depelopment for Latin America. New York, Saint Martin's Press, 1961.

20 Ver, a propósito, Brazil: an interim assessment of rural development projects for the Northeast. Washington, D.C., The World Bank, 1983, p. 60.

21 Tendler, Judith. New lessons from old projects: the workings of rural depelopment in Northeast Brazil. Washington, D.C., The World Bank Operations Evaluation Department, 1993.

22 Cf. Tendler, cit., p. 11-13.

23 Programa de Apoio ao Pequeno Produtor Rural do N̦ordeste. O Papp consolidou-se em 1985, com a Nova República, como uma revisão do Polonordeste. Cf. Seplan. I Plano Nacional de Desenvolvimento da Nova Repriblica - 1986-89 (projeto). Brasilia, 1985.

24 Cf. Albuquerque, R.C. de, Pobreza e exclusão social, cit. E também, do mesmo autor (coord.), O Brasil social, cit. Nesses estudos, são examinadas 36 situaçōes de pobreza no Brasil, bem como sua evolução no período 1970-90.

25 Os critérios adotados, portanto, já tomaram, a priori, em consideração algumas das variáveis relevantes para a explicação dos graus de pobreza, absoluta e relativa, bem como de sua evolução no tempo e de sua distribuição espacial.

26 Cf. Popper, Karl R. Objective knowledge. Oxford, Oxford Univ. Press, 1972. Popper distingue, numa perspectiva epistemológica, o que chama o "mundo dos objetos físicos ou estados físicos", o "mundo dos estados da consciência, ou estados mentais, ou, talvez, das disposições comportamentais para agir", e o "mundo dos conteúdos objetivos do pensamento". Partindo de Popper, Jarvie, I.C., em Concepts and society, Londres, 1972, propõe um mundo social independente, situado entre o bard mundo físico e o soft mundo mental (p. 165).

27 Os dados doravante utilizados referem-se - salvo quando expressamente indicado a 1990. Foram obtidos de tabulaçóes especiais, elaboradas com base na Pesquisa Nacional por Amostra de Domićlios (Pnad), do Ibge. Cf., para consulta às informações obtidas e à metodologia adotada, do autor, Pobreza e exclusão social, cit., bem como $O$ Brasil social, também referido.

28 Excluído o Norte rural, não considerado nas Pnads. 
29 Cf. Moura, Hélio A. \& Santos, Taís F. Nordeste: a dinâmica populacional recente e as novas perspectivas de crescimento populacional para o perfodo 1980-2005. In: Revista Económica do Nordeste, v. 21, n. 3/4, p. 395-441, jul./dez. 1990.

30 A capacidade de retenção relativa do incremento natural da população é medida pela diferença entre o crescimento demográfico líquido e o crescimento vegetativo, tomada como porcentagem deste último. Idem, p. 411.

31 Variaçáo ocorrida entre 1980 e 1991 (Fontes: Censos Demográficos de 1980 e.de 1991).

32 Esses percentuais não são aditáveis.

33 Veja-se Pobreza e exclusão social, cit. Observe-se que, nesses últimos indicadores, é principalmente o Nordeste rural que puxa os valores médios nacionais para baixo, em particular os rurais: os ICBs do Centro-Oeste, total e rural, são 582 e 271; os do Sul, 639 e 399; os do Sudeste, 731 e 355 (O ICB dos pobres do Nordeste rural é de 105 , o dos não-pobres, de 301). Sobre o ICB, ver a nota 14, supra.

34 Não se depreenda do que se segue que se esposa a tese do determinismo cultural como explicaçáo da pobreza, em oposição ao primado do econômico. O que se sugere é uma autonomia relativa dos fatores culturais com relação aos econômicosociais (e vice-versa) no condicionamento das situaçōes de pobreza, cabendo, ademais, notar que os primeiros têm em geral sido negligenciados no exame desse problema (salvo na literatura de natureza antropológica e etnográfica), a despeito da luz que podem trazer para seu mais amplo entendimento. Para competente exame dos aspectos económico-sociais da pobreza rural do Nordeste, veja-se Jatobá, Jorge, Rural poperty in Brazil's Northeast, Recife, 1993 (relatório preparado para o Banco Mundial, ainda em versão preliminar).

35 Veja-se, a propósito, Gusdorf, Georges, Mythe et méthaphysique, Paris, Flammarion, 1953 (tradução brasileira de Hugo di Prímio Paz, São Paulo, Convívio, 1980), p. 32-41 e 52-61.

36 No Nordeste rural, as práticas mágicas de manipulação da realidade incorporam, sincreticamente, as heranças religiosas indígena, católica e, embora em menor grau, africana. Promessas, catimbós, ex-votos e oferendas; penitências, jejuns e mortificações; procissões, romarias e novenas votivas; exorcismos (praticados pelas rezadeiras em casos de doenças de pessoas e de animais - ou de mau-olhado -, bem como para, por exemplo, eliminar as pragas dos roçados); a certeza de que vai chover no Dia de São José (19 de março) impelindo os agricultores do Agreste a plantar no seco; a queima de palha benta de coqueiro (do Domingo de Ramos) para afugentar as tempestades; crenças no Saci-Pererê, na Mãe-d'Água e em lobisomens são algumas de suas manifestaçōes mais comuns e que ainda hoje não deixam de apresentar, para muitos, resultados reconhecidamente objetivos.

37 Esse último ponto, como bem observa Jürgen Habermas, sendo característica da consciência mítica amplamente reconhecida desde Durkheim até Lévy-Strauss, além de ser consistente com práticas mágicas, não distingue as intervençóes no mundo da natureza das relaçóes interpessoais. Cf. Habermas, Jürgen, The theory of communicative action (Trad. Thomas McCarthy), Boston, Beacon, 1984. v. 1., p. 48. 
38 Nada é mais significativo dessa postura conformada do homem rural do Nordeste diante dos insucessos da vida e dos fenômenos adversos da natureza do que a expressão seja o que Deus quiser, invariavelmente verbalizada diante de situaçóes de privação ou infortúnio, da qual, aliás, não está ausente forte conotação de fatalismo.

39 Dados de 1990 . Ver a nota 27, supra.

40 Dado para 1976 (Pnad-Ibge). Ver, a propósito, Tolosa, H.C., Pobreza no Brasil: uma avaliação dos anos 80, in A questão social no Brasil, cit., p. 105-136.

41 Período 1976-88. Dados construidos a partir de Tolosa, cit.

42 Para o cálculo desse indicador (de distância social), ver a nota 13, supra. Cf., também, Albuquerque, Pobreza e exclusão social, cit., p. 59-60.

43 Essa diferença se deve, evidentemente, ao fato de ser maior, no Brasil como um todo, a incidência de pobreza (27\%).

44 Sobre o ICB - Índice de Carências Básicas -, ver as notas 14 e 33.

45 Note-se que os pobres dessas metrópoles costumam adquirir, muito mais facilmente e a menores custos, eletrodomésticos em segunda máo dentre os refugados pelos não-pobres mais afluentes. Vale, porém, observar que, tanto pelo critério-renda como pelos indicadores de bem-estar, os pobres da Grande São Paulo encontram-se em situação relativa precária. Sua renda média familiar (US\$ 183) é a mais baixa do pars, sendo inferior à do Nordeste rural (US\$ 214). O ICB, de 457, é inferior ao do Rio (460) e ao de Belo Horizonte (499). Para tentativa de explicação desse último fenômeno, ver Albuquerque, Pobreza e exclusão social, cit.

46 Esses percentuais não são aditáveis. Observe-se que o percentual de famílias chefiadas por menores é algo mais elevado no Rio de Janeiro $(1,2 \%)$ e que o de chefes de família idosos é maior em São Paulo (13\%).

47 Seria este o modo de ạnálise prototípico da sociologia urbana de inspiração norteamericana ao gosto de Park ou de Wirth [Cf. Velho, Otávio G. (org.), O fenómeno urbano, 4. ed., Rio de Janeiro, Zahar, 1979, que publica, no Brasil, os antolbgicos textos desses dois destacados expoentes da chamada Escola de Chicago].

48 Ao modo, por exemplo, de Weber (Cf. Weber, Max, Economia y sociedad, trad. J.M. Echevarría e outros, México, Fondo de Cultura, 1964, v. 2) ou de Marx (Cf. Marx, Karl, $O$ capital: critica da economia politica, trad. R. Barbosa e Flávio F. Kothe, São Paulo, Abril, 1983, v. 1, t. 1, p. 278, e t. 2, p. 101-102).

49 Os domicflios das favelas do Sudeste metropolitano correspondem (1991) a 5,3\% do total de domicílios (10,3\% em Belo Horizonte, $9,8 \%$ no Rio de Janeiro e 3,8\% em São Paulo), percentuais bastante inferiores aos relativos às incidências de pobreza observadas (1990), que foram, respectivamente, de $9,7 \%, 16,1 \%, 13,1 \%$ e $6 \%$. Nos três espaços metropolitanos, embora as favelas tendam a concentrar-se nos municípios das capitais (correspondendo a $80 \%$ de seus domićlios: $70 \% \mathrm{em}$ Belo Horizonte, $77 \%$ em São Paulo e $86 \%$ no Rio de Janeiro), a incidência de pobreza é 
maior nos municípios periféricos. Cf., para favelas, o Anuário Estatístico do Ibge de 1992, p. 87-88, e, para as incidências de pobreza centro-periferia, Rocha, Sonia \& Tolosa, Hamilton C., Núcleo-periferia metropolitana: diferenciais de renda e pobreza, in Pobreza e mobilidade social, cit., p. 137-171. Muitos pobres (em especial os migrantes mais recentes), não têm hoje fácil acesso às favelas dos municípios metropolitanos centrais, as quais crescentemente abrigam o que se poderia considerar como baixa classe média.

50 Veja-se, como exemplo da visão do favelado como marginal, Bonilla, Frank, Rio's favelas: the rural slum within the city, in Mangin, William (ed.), Peasants in cities: readings in the antropology of urbanization, Boston, H. Miflin, 1970, p. 75-77. E, como visão do favelado pobre como culturalmente integrado, Perlman, Janice E., $O$ mito da marginalidade: fapelas e política no Rio de Janeiro. Rio de Janeiro, Paz e Terra, 1977.

51 Ressalve-se, contudo, que trabalho recente, sobre experiência de promoção social comprometida com os valores da cidadania, participação popular e direitos humanos realizada no Morro da Coroa, no Rio de Janeiro, aponta inúmeras dificuldades nessa tarefa, decorrentes de obstáculos de natureza cultural em tudo semelhantes aos considerados neste estudo como dominantes apenas no Nordeste rural. Cf. Duarte, Luiz F.D.; Barsted, Leila L.; Taulois, Maria R. \& Garcia, Maria H., Vicissitudes e limites da conversão à cidadania nas classes populares brasileiras, Revista Brasileira de Ciências Sociais, n. 22, ano 8, 1993, p.7-19.

52 Veja-se, a propósito do coronelismo rural, Vilaça, Marcos V. \& Albuquerque, Roberto C. de, Coronel, Coronéis, 3. ed., Rio de Janeiro, Tempo Brasileiro, 1988 (1. ed., 1965).

53 Dados de 1990. Ver a nota 27, supra.

54 As estatísticas nacionais (Ibge) consideram áreas urbanas aquelas definidas como tais por lei municipal, que incluem as sedes dos municípios (cidades) e dos seus demais distritos (vilas). Esse critério, de natureza político-administrativa, considera como urbanas aglomerações humanas de pequeno porte, geralmente de feição nitidamente rural. Alguns estudos sobre urbanização no Brasil têm considerado como urbanas as localidades com populaçáo igual ou superior a determinado limite (20 mil habitantes, por exemplo). Cf. Martini, George; Beltrão, Kaizô; Camarano, Ana Amélia \& Neupert, Ricardo, A urbanização no Brasil: retrospectiva, componentes e perspectiva. In: Prioridades e perspectivas de politicas públicas para a década de 90 , v. 3 , Brasília, Ipea, 1990, p. 99-159.

55 Veja-se Tolosa, H.C., cit., p. 105-136. Observe-se que a pobreza metropolitana decresceu ainda mais intensamente: de cerca de 1,4 milhão para 0,8 milhão no período, ou de $50 \%$ para $20 \%$ da população total das três metrópoles regionais.

56 Cf. Moura \& Santos, cit., p. 411. O meio urbano do Nordeste, que, na década de 1960, absorvera pelas migraçóes apenas $19 \%$ do crescimento vegetativo da população rural regional, reteve, na década de $1970,34 \%$ dele.

57 Essa análise será feita apenas para o Nordeste urbano como um todo, destacando-se o caso das regiōes metropolitanas quando existirem diferenças relevantes. 
58 Nas famílias não-pobres do Nordeste urbano 2,1 pessoas em idade ativa geram cerca de $30 \%$ da renda familiar.

59 No Nordeste rural, o percentual de chefes de família pretos é, para os pobres, 6,9\%; para os não-pobres, $7,0 \%$; o de pardos é, para os pobres, $68,7 \%$; para os nãopobres, $62,9 \%$. A correlação entre cor e pobreza é mais alta em Salvador do que no Rio de Janeiro, Belo Horizonte ou Recife. Estudo apresentado, em 1993, no V Fórum Nacional (Cf. Valle Silva, Nelson do, Situação social da população negra, in Pobreza e mobilidade social, cit., p. 175-198) conclui, com base em amplo conjunto de indicadores, pela evidência de "claros indícios da presença [na sociedade brasileira] de mecanismos discriminatórios, de base racial, que se dão ao longo de todo o processo de realização sócio-econômica individual" (p. 195).

60 Observe-se, contudo, que o analfabetismo ainda é elevado entre os chefes de família não-pobres do meio urbano regional $(25 \%)$, sendo provavelmente mais alto entre os mais velhos ( $55 \%$ deles têm mais de 40 anos). Nas regiôes metropolitanas, a taxa de analfabetismo entre os não-pobres só é sensivelmente mais baixa no Recife (17\%) e em Salvador (9\%).

61 Recorde-se que essa incidência é de $69 \%$ no meio rural do Nordeste e de menos de $10 \%$ no Sudeste metropolitano.

62 Cabe observar, conforme aliás já sugerido anteriormente, que essa categorização tem significado sobretudo ideativo, sendo de escassa verificação empírica: os pobres urbanos, pelo menos no Brasil de hoje, continuam sendo pobres não porque não se achem inseridos na sociedade que os envolve mas porque as formas dessa inserção não são capazes de prover-lhes os meios de atendimento de suas necessidades básicas.

63 Essa palavra foi cunhada por Gilberto Freyre e por ele amplamente utilizada, embora em outro contexto. Cf., desse autor, Sugestōes para uma nova politica no Brasil: a rurbana, de 1957, publicada em Quase política, 2. ed., Rio de Janeiro, José Olympio, 1966.

64 João Paulo dos Reis Velloso (em Inovação e sociedade cit., p. 79) já deixa suficientemente clara a necessidade de integrar o social na estratégia econômica. Em trabalho mais recente (Modernidade e pobreza: a construção da modernidade cconômicosocial no Brasil, publicado em Modernidade e pobreza, São Paulo, Nobel, 1994, p. 977), Velloso aprofunda a discussão do tema, concebendo modelo integrado (econômico-social) como alternativa de estratégia social.

65 É evidente que, nesse exercício, a taxa de crescimento necessária para eliminar a pobreza varia em função da incidência de pobreza, do nível da renda familiar per capita total e da diferença entre as rendas médias de pobres e não-pobres. Para São Paulo, essa taxa seria de apenas $0,5 \%$, para o Rio de Janeiro, $0,9 \%$, para Belo Horizonte, $1,2 \%$, para o Brasil como um todo, $2,9 \%$. Cf., para os dados básicos que ensejam esses cálculos, Albuquerque, Pobreza e exclusão social, cit.

66 Para exame de proposta educacional comprometida com a modernidade, veja-se Velloso, J.P. dos Reis \& Albuquerque, R.C. de (orgs.), Educação e modernidade, São Paulo, Nobel, 1993. 
67 Desconsidera-se propositalmente neste estudo a hipótese de reduçáo da pobreza sem crescimento, ou seja, de redistribuição estática de renda, em benefício dos pobres. A análise da evolução das situaçōes sociais empreendida sugere que esse jogo de soma zero, conquanto possível, é muito pouco provável no Brasil, entre outras razóes pela dimensão de sua pobreza, pelo nível relativamente baixo da renda per capita do país e pelo limitado poder de barganha dos pobres na disputa por parcelas crescentes de produto nacional. Admite-se, portanto, que o crescimento, acompanhado da capacitação dos pobres para inserção mais produtiva na economia, é sequiência de combate à pobreza mais factível e menos conflituosa.

68 Cf. Costa, Manoel A., O problema demográfico e as migraçóes internas, em Estratégia social e desenpolvimento, cit., p. 75-119. Observe-se que a população em idade ativa (15-64 anos) no Brasil deverá elevar-se dos atuais 96,4 milhōes (1994) para 108,1 milhões no ano 2000, ou seja crescerá em 11,7 milhões

69 Os Ministérios do Trabalho e da Educação poderiam coordenar essas açóes, com o apoio de suas contrapartes nos estados, a orientaçáo técnica de entidades como o Senai, o Senac e o Senat, e em articulação com a iniciativa privada. No que respeita à organização mais racional dos serviços por conta própria, o exemplo das cooperativas de taxistas poderia ser facilmente replicado nos serviços de instalação, manutenção e reparo, envolvendo eletricistas, bombeiros, carpinteiros, pedreiros e muitos outros ofícios, de que hoje tanto carecem as maiores cidades brasileiras. Não é, contudo, propósito deste estudo enveredar - a não ser en passant - pelo nível programático.

$70 \mathrm{O}$ artesanato, os pequenos negócios industriais e comerciais (na área de alimentos e, em geral, de produtos regionais), direcionados aos mercados nacional e externo ou para a procura gerada pelo turismo, são exemplos dessas atividades.

71 No primeiro caso, a agroindústria (inclusive a produção de insumos e de serviços utilizados pela agricultura) pode constituir-se elo de uma integração sinergética pequena cidade-campo. Exemplo de fértil interligação produtiva com os mercados regional e nacional é o de Santa Cruz do Capibaribe, cidade, situada no Agreste de Pernambuco, que se especializou nos pequenos negócios, a maioria de base familiar, de confecção de roupas, comercializadas a preços módicos em todo o país.

72 Também neste caso, a moderna agroindústria poderá ser alavanca importante para que essa transformação se opere e amplie, à medida em que a produção de parcela das matérias-primas de que necessitem esteja a cargo de pequenos produtores rurais, aos quais sejam facilitados assistência técnica, crédito e garantia de mercado.

73 Considera-se que foi principalmente a ausência de esforço dessa natureza que afetou o desempenho dos programas de desenvolvimento rural integrado do Nordeste.

74 Não há como negar validade à concessão de subsídios governamentais (para garantir o acesso à terra, ao crédito e mesmo como forma de suplementar o consumo e a renda) nessa fase de transformação do pobre rural em pequeno produtor capaz, com sua família, de prover suas necessidades básicas, assim superando, com nova postura perante o trabalho e, em geral, a vida, o círculo vicioso da miséria. 
75 Os estudos internacionais sobre políticas públicas antipobreza rural consideram geralmente um número muito maior de variáveis e componentes [Cf., por exemplo, o recente The state of the world rural poperty: an inquiry into its causes and consequences, de autoria de Idriss Jazairy, Mohiuddin Alamgir e Theresa Panuccio, New York, New York Univ. Press, 1992 (publicado para o Fundo Internacional para o Desenvolvimento da Agricultura)]. Na visão do autor deste estudo, esta multiplicidade, embora útil do ponto de vista analítico, complica desnecessariamente as intervençóes públicas em situaçóes de pobreza, comprometendo-lhes a eficácia e elevando seus custos.

76 A execução descentralizada dessas políticas públicas (da União para os estados e municípios), atuando a União para compensar as deficiências financeiras e técnicas dos estados e dos municípios menos desenvolvidos, pode ser, nesse contexto, medida capaz de contribuir para que se obtenha, mais rápida e eficazmente, esse efeito equalizador.

77 A descentralização executiva e o envolvimento comunitário devem, na verdade, constituir diretrizes básicas de todas as ações antipobreza sugeridas neste estudo. Descentralização e participação vistas, evidentemente, não como um fim em si mesmo mas um meio para que se obtenha sua necessária focalização, bem como para que se alcancem mais eficiência e eficácia.

78 Veja-se, a propósito, Porto, Cornélia N.; Costa, Iraci del Nero da \& Nozoe, Nelson Hideiki, A estrutura das famílias na cidade e no campo: uma análise inter-regional, em Delgado, Guilherme Costa; Gasques, José Garcia \& Villaverde, Carlos Monteiro, Agricultura e políticas públicas, Brasília, Ipea, 1990, p. 225-278.

79 Veja-se Costa, Manoel A., cit., p. 82-87. Surpreende que muitas mulheres pobres do Nordeste rural com prole já numerosa solicitem aos médicos a esterilização (de acordo com depoimentos esparsos colhidos in loco pelo autor deste estudo).

80 Os dados disponíveis não permitem precisar o percentual de pobres nessa situação. Estimativa muito tentativa indica que esses grupos representam entre $45 \%$ e $50 \%$ do total de pobres do país, ou seja, algo entre 16 a 20 milhóes de pessoas em 1990.

81 Para visão liberal da lei e da ordem no moderno Estado de direito, veja-se Dahrendorf, Ralf, A lei e a ordem, trad. Tamara D. Barille, São Paulo, Conselho Liberal, 1993 (Série Cadernos Liberais, 2).

\section{Resumo}

Neste estudo, partindo-se de concepção do desenvolvimento como processo global (econômico, social e político), propôe-se formular modelos de intervenção pública em situaçóes de pobreza, com o objetivo de superar o que se considera um dos maiores desafios para a modernização dos países menos avançados. Os modelos propostos são concebidos a partir da análise e interpretação detalhadas de três diferenciadas situações de pobreza no Brasil: o Nordeste rural (área considerada de baixa renda, ou subdesenvolvida), o Sudeste metropolitano (de nível médio-alto de desenvolvimento) e o Nordeste urbano (nível médio-baixo). Pretendem, porém, ter validade mais geral como enquadramentos a partir dos quais programas de combate à pobreza específicos, inseri- 
dos em estratégias de desenvolvimento, podem ser formulados e executados. O núcleo dos modelos é integrado por três variáveis básicas, às quais correspondem três ações estratégicas: o crescimento, com a indentificação dos mecanismos pelos quais os pobres podem dele se beneficiar; o conhecimento, representado pelo capital humano, de que decorre esforço de educação básica e de qualificação da pobreza; e o trabalho, considerado como variável-enlace entre o crescimento e o conhecimento, pelo qual se dá a inserção produtiva dos pobres e sua autopromoção social. São consideradas ainda ações complementares, envolvendo a extensão aos pobres das políticas sociais públicas; o planejamento familiar; a intensificação do uso do trabalho como forma de suplementação de renda; a assistência aos pobres considerados mais vulneráveis; e a extensão, a eles, dos direitos da cidadania, assegurados pela presença do Estado nas áreas de concentração de pobreza.

\section{Abstract}

The paper initially considers development a global process (at the same time an economic, social and political phenomenon) and discusses its implications for the modernization paths adopted by the less-advanced countries. This the basis for the proposition of public intervention models aimed at overcoming poverty situations, viewed as the major development challenge of these nations. The models proposed were conceived on the bases of detailed analyses of three different poverty situations in Brazil: the rural Northeast (an underdeveloped, or low-income area); the metropolitan Southeast (an upper middleincome area); and the urban Northeast (a lower middle-income area). Nonetheless, they intend to have more widespread validity as frameworks from which specific antipoverty programs may be conceived and implemented, as a part of development strategies. The models' nucleus is integrated by three basic variables and their correspondent strategic actions. The first one is growth and involves the mechanisms through which the poor can benefit from it are analyzed. The second is knowledge, embodied in human capital, which commands an effort of basic education and jobtraining aimed at the poor. The third is labor, a link-variable between growth and knowledge that provides the productive insertion and social self-promotion of the poor. The models include some complementary actions. They involve essentially social public policies targeted to the poor; family planning; the more intensive use of labor as a means to supplement income; assistance to the more vulnerable poor; and the extension of citizenship, provided mainly by the presence of the State in poverty concentration areas.

Roberto Capalcanti de Albuquerque é diretor técnico do Instituto Nacional de Altos Estudos (Inae). Ex-secretário de Planejamento da Presidência da República e superintendente do Ipea. Professor titular, fundador e diretor do Programa Integrado de Mestrado em Economia e Sociologia (Pimes) da Universidade Federal de Pernambuco.

Trabalho apresentado no seminário Desenvolvimento social e pobreza, organizado pelo Ministério das Relaçōes Exteriores como preparação para a Cúpula Mundial para o Desenvolvimento Social (São Paulo, setembro de 1994). 